\title{
I8. Yüzyıl Sonunda Ayanlık Siyaseti ve Germiyanzâdeler
}

Murat Dağll $l^{*}$

The Politics of the Local Notables at the end of the 18th Century and the Germiyanzâdes

Abstract $\square$ Studies on the local notables in the 18th century have become one of the best studied subjects in Ottoman history. Both empirical studies and theoretical approaches have considerably expanded the scope of research. However, as most of the studies focus on the powerful local notables, our knowledge on the local notables who were relatively less powerful is still limited. This essay is on one of the lesser ayans: the Germiyanzâdes in Kütahya. Germiyanzâdes in Kütahya. Even though the main purpose of the essay is to provide concrete evidence on the social and economic power of the Germiyanzâdes at the end of the 18th and the beginning on the 19th century, it also provides a comparative perspective taking into account the other local notables in and around the same region, and and makes certain suggestions on the dynamics of the politics of the local notables as well as on the effects of financial and administrative centralization initiated by the central authority.

Keywords: Germiyanzâde, Kütahya, politics of the local notables, the $18^{\text {th }}$ Century, centralization.

\section{Giriş}

18. yüzyıl uzun zamandan beri Osmanlı tarihinin ayanlar dönemi olarak nitelendiriliyor. Bu dönem ve ayanlarla ilgili çalışmalar da artık gerek kuramsal

* Bilgi Üniversitesi, e-posta: muratpdagli@gmail.com Makalenin son halini almasındaki uyarı ve tavsiyeleri için derginin hakemlerine teşekkür ederim. 
gerekse ampirik olarak kendi başına bir araştırma alanı olarak nitelendirilebilir. ${ }^{1}$ Bilgi birikiminin belli bir noktaya ulaştığı çalışma alanlarında eksiklikler ya da sıradışı konular bulmak kolay değil; yine de tüm bilgi birikimi ve farklı kuramsal

1 Tümüyle kapsayıcı olmamakla beraber bu araştırmaların bazıları; Yuzo Nagata, MuhsinZâde Mehmed Paşa ve Ayanlık Müessesesi (Tokyo: Institute for the Study of Languages and Cultures of Asia and Africa, 1976); Yuzo Nagata, Tarihte Ayanlar Karaosmanoğulları Üzerine Bir Inceleme (Ankara: Türk Tarih Kurumu, 1997); Yuzo Nagata, "Karaosmanoğlu Hacı Hüseyin Ağa'ya Ait Bir Tereke Defteri," IX. Türk Tarih Kongresi, (Ankara: Türk Tarih Kurumu, 1988), s. 1055-1063; Yuzo Nagata ve Feridun Emecen, "Bir Ayanın Doğuşu: Karaosmanoğlu Hac1 Mustafa' ya Ait Belgeler,” Belgeler - Türk Tarih Belgeleri Dergisi XXV/29 (2004), s. 1-73; Yücel Özkaya, Osmanlı Imparatorluğu’nda Ayanlık, (Ankara: Türk Tarih Kurumu Basımevi, 1994); Ali Yaycıoglu, “The Provincial Challenge: Regionalism, Crisis and Integration in the Late Ottoman Empire (1792-1812)”, (Ph.D., Harvard University, 2008); Ali Yaycioğlu, Partners of the Empire, The Crisis of the Ottoman Order in the Age of Revolutions (Stanford, California: Stanford University Press, 2016); Canay Şahin, "The Economic Power of Anatolian Ayans of the Late Eighteenth Century: The Case of Caniklizâdes," International Journal of Turkish Studies, 11 (2005), s. 29-49; Hüseyin Çınar, "18. Yüzyılda Ayıntab’da Bir Yerel Gücün Yükselişi ve Düşüşü: Battalzâdeler,” XIV. Türk Tarih Kongresi, (Ankara: Türk Tarih Kurumu, 2005), s. 432-452; Yavuz Cezar, "Bir Âyanın Muhallefatı, Havza ve Köprü Kazaları Âyanı Kör İsmail-Oğlu Hüseyin, Müsadere Olayı ve Terekenin İncelenmesi,” Belleten, 41 (1977), s. 41-78; Suraiya Faroqhi, "Wealth and Power in the Land of Olives: Economic and Political Activities of Müridzade Hacı Mehmed Ağa, Notable of Edremit," Landholding and Commercial Agriculture in the Middle East, Çağlar Keyder, Faruk Tabak, (eds.), (New York: State University of New York Press, 1991), s. 77-96; Melek Öksüz, Onsekizinci Yüzyılın İkinci Yarısında Trabzon, (Trabzon: Serander, 2009); Muhammed Aydın, Sivas'ta Âyan Aileleri, 1740-1850, (Sivas: Sivas Belediyesi, 2015); Deena Sadat, "Rumeli Ayanları: The Eighteenth Century," Journal of Modern History 44 (1972), s. 346-363; Antonis Anastasopoulos (ed.), Provincial Elites in the Ottoman Empire, Halcyon Days in Crete V a Symposium Held in Rethymno 10 - 12 January 2003 (Rethymno: Crete University Press, 2005); Robert W. Zens, "Provincial Powers: The Rise of Ottoman Local Notables," History Journal 3 (2011), s. 433-447; Robert W. Zens, "In the Name of the Sultan: Hacı Mustafa Pasha of Belgrade and Ottoman Provincial Rule in the Late 18th Century," International Journal of Middle East Studies 44 (2012), s. 129 - 146; Antonis Anastasopoulos ve Elias Kolovos, (Eds.), Ottoman Rule and the Balkans, 1760-1850 Conflict, Transformation, Adaptation - Proceedings of an International Conference Held in Rethymno, Greece, 13-14 December 2003 (Rethymno: University of Crete Department of History and Archaeology, 2007); Bruce McGowan, "The Age of the Ayans 1699-1812," An Economic and Social History of the Ottoman Empire 1600-1914, Donald Quataert, Halil İnalcık (eds.), (Cambridge: Cambridge University Press, 1997), s. 637-758; Bekir Sıtkı Baykal, "A'yanlık Müessessesinin Düzeni Hakkında Belgeler," Belgeler - Türk Tarih Belgeleri Dergisi 1 (1964), s. 221-227; Margaret L. Meriwether, The Kin Who Count, Family and Society in Ottoman Aleppo, 1770-1840 (Austin: University of Texas Press, 1999); Dina Rizk Khoury, Osmanl Imparatorluğu'nda Devlet ve Taşra Toplumu, Musul 1540-1834 Ülkün Tansel (çev.), (İstanbul: Tarih Vakfı Yurt Yayınları, 1999). 
yaklaşımlara rağmen ayanların genel olarak kabul görmüş bir sınıflandırma çerçevesinde değerlendirildiği söylenemez. Bir örnek vermek gerekirse, Donald Quataert, 2000 tarihli Osmanlı Taribi, 1700-1922, kitabında genel bir sınıflandırma önermişti. ${ }^{2}$ Quataert'e göre ayanlar, her birinin farklı birer sosyal bağlamı temsil ettiği üç farklı grupta sınıflandırılabilir. Birinci grupta eyaletlere atanıp oradamerkezî yönetimin bunu engelleme çabalarına rağmen—kök salan ve yerlileşen ayanlar var. Şam'daki al-Azm ailesi, Musul'da Celili aşireti ${ }^{3}$ ya da Batı Anadolu'daki Karaosmanoğulları bu gruba dahiller. İkinci gruptakiler sadece Arap eyaletlerinde ortaya çıkan ve kökenleri Memlük askerlerine kadar giden ayan aileleri. ${ }^{4} \mathrm{Bu}$ gruba dahil olanlar Osmanlı yönetimi boyunca Arap eyaletlerine dışarıdan gelen, azâd edildikten sonra kendi kapı halkını kuracak kadar etkili Memlük aileleri; Mısır'da Kavalalı Mehmed Ali Paşa hizmetinde bulunduktan sonra Sayda’yı yöneten Ahmed Cezar Paşa ve ailesi gibi.

Üçüncü grupta ise, beylikler döneminde belli bir bölgeye yerleşmiş ve orayı kontrol etmiş ayan aileleri var. Bu aileler Osmanlı devletine ilhak edilmiş olsalar da varlıklarını yüzyıllarca sürdürebilmiş ve özellikle 18. yüzyılda yerel olarak yeniden ortaya çıkmış ayan aileleri. Quataert kendi sınıflandırması içinde bu gruba örnek olarak sadece olarak Bosna'daki büyük toprak sahiplerini göstermekte ve tarihçilerin bu gruba dahil olabilecek ayanların iktidarlarını yüzyıllar boyunca nasıl koruduklarını gözardı ettiklerini iddia etmektedir. ${ }^{5}$ Quataert' in sınıflandırmasının işlevsel olup olmadığı yönünü bir kenara bırakacak olursak, ${ }^{6}$ bu yazıda

2 Donald Quataert, The Ottoman Empire 1700-1922, New Approaches to European History, (Cambridge: Cambridge University Press, 2000), s. 46-51.

3 Merkezî idarenin Şam ve Musul'daki rolü ve ayan ailelerini ne dereceye kadar kontrol etmeye çalıştığı tartışmalıdır. Bruce Masters, "Semi-Autonomous Forces in the Arab Provinces," The Cambridge History of Turkey, the Later Ottoman Empire, 1603-1839, Suraiya N. Faroqhi, (ed.), (Cambridge: Cambridge University Press, 2009), s. 193.

4 Bu konuda Jane Hathaway'ın çalışmaları özellikle anılmalıdır. Jane Hathaway, The Politics of Households in Ottoman Egypt: The Rise of the Qazdaglis (Cambridge: Cambridge University Press, 1997); Jane Hathaway, "The Household: An Alternative Framework for the Military Society of Eighteenth-Century Ottoman Egypt," Oriente Moderno, 18 (1999), s. 57-66; Jane Hathaway, The Arab Lands under Ottoman Rule 1516-1800 (London: Pearson Longman, 2008).

5 Quataert, The Ottoman Empire, s. 46-47.

6 Bir başka sınıflandırma denemesi için, Zens, "Provincial Powers: The Rise of Ottoman Local Notables.” Donald Quataert'in yaptığına benzer bir sınıflandırmayı, Bruce Masters Arap toprakları için yapar. Masters, Quataert'in üçlü sınıflandırmasına aşiret gruplarını da ekler, bk, Masters, "Semi-Autonomous Forces in the Arab Provinces" s. 186-187. Bunlara 18. yüzyıl boyunca yerel vergileri toplamaktan eşkıyalığa kadar farklı siyasî-iktisadî ve şiddet gibi yolları kullanarak yükselen bir gruptan da bahsedilebilir. Dina Rizk Khoury, ayanları 
söz konusu olan tam da Quataert’in tarihçilerin biraz gözardı ettiğini söylediği bu üçüncü gruptan bir ayan ailesi: Germiyanzâdeler.

Germiyanzâdeler Beylikler döneminin başat aktörlerinden biri olarak uzun zamandır farklı yönleriyle incelenmiştir. İsmail Hakkı Uzunçarşılı, erken sayılabilecek bir zamanda, henüz 1932'de, Germiyanzâdeler üzerine ilk derli toplu çalışmayı yapmıştı. ${ }^{7}$ Daha sonra özellikle Mustafa Çetin Varlık, bu konu üzerine daha kapsamlı olarak çalışmaya devam etti ve siyasi, ekonomik, ve sosyal tarih çalışmaları ile Germiyanzâdeleri ele aldı. ${ }^{8}$ Ayrıca, Osman Uysal beyliğin mimarî tarihi üzerine geniş hacimli bir çalışma yayınladı. ${ }^{9}$ Mustafa Koç'un çalışması da beyliğin kültürel ve ilmî yönlerini araştırd ${ }^{10}{ }^{10} \mathrm{Bu}$ çalışmalar Germiyanzâdeler hakkında bir bilgi birikimi sağlamışlardır.

Bu çalışmanın da amacı özellikle 18. yüzyılın son çeyreğine odaklanarak Germiyanzâdeler hakkında bu bilgi birikimine katkıda bulunmaktır. Bunu yaparken Germiyanzâdeleri diğer bölge ayanları ile karşılaştırmak genel bir bağlam oluşturmak açısından da önemlidir. Dolayısıyla yazının amacı ayanlık literatürüne kavramsal ya da kuramsal bir katkıdan ziyade bu tartışmaların üzerine oturabileceği ampirik veri zeminini genişletmektir. Germiyanzâdelerin devamlılı̆̆ 1 çok önemli ve ilginç bir araştırma konusu olmakla birlikte, 18. yüzyılın son çeyreğine odaklanmanın bazı somut nedenleri de vardır. Her şeyden önce, birincil kaynaklardaki-15. yüzyıldan 17. yüzyılın sonuna uzanan--boşluk süreklilikleri tatmin edici bir şekilde takip etmeyi imkânsızlaştırmaktadır. Burada özellikle üzerinde durulan Kütahya kadı sicilleri de sadece 18. yüzyılın son çeyreği için verimli bir kaynaktır. Germiyanzâdeler 18. yüzyılda çok fazla göz önünde olmadıkları ve devleti doğrudan tehdit etmedikleri için büyük ayanlara kıyasla tarihçilerin

tanımlamanın ve sınıflandırmanın güçlüklerinden bahseder, bk. Dina Rizk Khoury, "The Ottoman Centre Versus Provincial Power-Holders: An Analysis of the Historiography," The Cambridge History of Turkey, the Later Ottoman Empire, 1603-1839, Suraiya N. Faroqhi (ed.), (Cambridge: Cambridge University Press, 2009), s. 135-157.

7 İsmail Hakkı Uzunçarşılı, Bizans ve Selçukiylerle Germiyan ve Osman Oğulları Zamanında Kütahya Şehri (İstanbul: Devlet Matbaası, 1932).

8 Mustafa Çetin Varlık, Germiyan-Oğulları Tarihi (1300-1429), (Ankara: Ankara Üniversitesi Yayınları, 1974); Mustafa Çetin Varlık, "Germiyanoğulları Beyliği," Anadolu Selçukluları ve Beylikler Dönemi, Sosyal ve Siyasal Hayat, Ahmet Yaşar Ocak (ed.), (Ankara: T.C Kültür ve Turizm Bakanlığı, 2006) s. 153-159; Mustafa Çetin Varlık, "Kütahya’nın Şehzade Sancağı Olarak İdaresi,” Marmara Üniversitesi Türklük Araştırmaları Dergisi, 5 (1989), s. 314-324.

9 A. Osman Uysal, Germiyanoğullar Beyliğinin Mimarî Eserleri, (Ankara: Atatürk Kültür Merkezi Başkanlığı Yayınları, 2006).

10 Mustafa Koç, “Germiyanoğulları Beyliği’nde İlmî ve Kültürel Hayat” (Yüksek Lisans Tezi, Dokuz Eylül Üniversitesi, 2007). 
dikkatini pek çekmiyor olabilir. ${ }^{11}$ Oysa ki daha az görünür bu ayan ailelerini incelemek, merkezî idarenin 19. yüzyılda iktidarını nasıl yeniden ve daha güçlü olarak kurduğu hakkında da daha iyi fikir sahibi olmamıza yarayabilir. Bu araştırma da kendi dinamikleri içinde değerlendirilmesi gereken Tanzimat dönemine uzanmadan, 1820'leri sınır olarak almaktadır. Bu dönemin öncesi ve sonrası için yapılan tespitlerin ve ileri sürülen fikirlerin yeni ve daha derinlemesine yapılacak araştırmalarla geliştirilmesi umulur.

Artık 18. yüzyılda Osmanlı devletinin mutlak olarak zayıfladığı iddia edilemese de bu dönem merkezî idarenin alternatiflerinin ortaya çıktığı bir dönem olarak görülüyor. ${ }^{12} 17$. yüzyılda başlayan ve 18 . yüzyılda devam eden sosyo-ekonomik dönüşümün Osmanlı siyasetini yeniden tanımladığının en açık belgesi ise Sened-i İttifak (1808). ${ }^{13}$ Eğer Sened-i İttifakı—belgedeki tüm muğlaklığa rağmen-merkezin çevreyle, ya da bürokrasinin ayanlarla yaptı̆̆ bir anlaşma olarak görmek mümkünse, nasıl oluyor da, çok kısa bir sürede, merkezî idare iktidarını yeniden kurabiliyor? Eğer 19. yüzyılın hemen başında siyasi yapı yeni bir biçim almaya başlıyor ve ayanlar bunda önemli bir rol oynuyorsa, nasıl oluyor da neredeyse yirmi yıl gibi kısa bir sürede bu yeni siyasi yapının en önemli aktörleri yerlerini daha da merkezî bir idareye bırakıyor? Bu gibi sorulara yanıt bulabilmek için ayanların gücü ve kendi aralarındaki rekabet hakkında kavramsal tartışmalar kadar somut verilerle desteklenen geniş ve karşılaştırmalı bir yaklaşım verimli olacaktır.

Araştırmacıların üzerinde uzlaştıkları konulardan biri 18. yüzyıl boyuncaözellikle yüzyılın ikinci yarısından itibaren—merkezî yönetimin idarî ve hukukî yapısında önemli değişiklikler olduğu ve bu değişikliklerin farklı karar alma süreçlerini-özellikle yerel idareler söz konusu olduğunda—daha temsilî yaptığ..$^{14}$ Yine de ayanların başat güçlerden olduğu bu süreç tüm toplumu kapsayan radikal

11 Yücel Özkaya'nın son derece kapsamlı çalışması içinde de Germiyanzâdeler kendilerine neredeyse hiç yer bulamamışlar. Özkaya, Osmanl İmparatorluğu’nda Ayanlık, s. 161. Ayanlar üzerinde yakın tarihli ve karşılaştırmalı bir değerlendirme yapan Robert Zens de görece daha küçük yerel ayanların yeteri kadar çalışılmadığı fikrindedir ("Provincial Powers”, s. 435).

12 Karen Barkey, Empire of Difference, the Ottomans in Comparative Perspective (Cambridge, New York: Cambridge University Press, 2008) ve özellikle, Yaycioğlu, Partners of the Empire.

13 19. yüzyılın dönem noktası olan Sened-i İttifak, Tanzimat ve Islahât fermanları için, Tanzimat, Değişim Sürecinde Osmanlı Imparatorluğu Halil İnalcık, Mehmet Seyitdanlığlu (ed.), (İstanbul: Türkiye İş Bankası Kültür Yayınları, 2012), s. 3-25, Senedi-i İttifak metninin bir tahlili için, Halil İnalcık, "Sened-i İttifak ve Gülhane Hatt-1 Hümâyûnu," Osmanlı İmparatorluğu, Toplum ve Ekonomi, (İstanbul: Eren, 1993), s. 343-359.

$14 \mathrm{Bu}$ görüşün ilk örneklerinden biri olarak, Halil İnalcık, "Centralization and Decentralii zation in Ottoman Administration," Studies in 18th Century Islamic History, Thomas Naff, 
taleplerin olduğu bir kırılma noktası değil; daha ziyade iktidar ilişkilerinin seçkinler arasında yeniden şekillendiği bir dönemdir. Bu yüzden merkezî iktidarın gücünü nasıl yeniden kurduğunu anlatırken Dina Rizk-Khoury'nin belirttiği gibi kapsayıcı bir açıklama için daha fazla veri ve karşılaştırmalı araştırmalara dayalı bir yaklaşım gerekli gözükmektedir. Bunu yaparken ise merkezle çevredeki ayanların değişen ilişkisine bakmak şart ama bunu sadece en tepedeki ayanlarla sınırlamak yanıltıcı olabilir; Rizk-Khoury'nin önerisi, en tepedekiler kadar siyasî iktidar hiyerarşisinde Germiyanzâdeler gibi çok da görünür olmayan ayanlara bakmak; çünkü bu kesim 19. yüzyılda Osmanlı devletinin taşradaki belkemiğini oluşturacak kesimdir. ${ }^{15}$

Germiyanzâdeler aynı zamanda Osmanlı hanedanından uzun süren ömürleri ile de ilginç bir örnek teşkil etmektedir. Germiyanzâdeler beylikler döneminde Osmanlılardan önce Anadolu'ya yerleşmişlerdi. Aile mensupları Tanzimat döneminde Adliye Nazırlığına kadar yükselip, II. Abdülhamit döneminde saraya damat bile oldular. ${ }^{16}$ İmparatorluk dağılıp, Osmanlı hanedanlığı sona erdikten sonra da yeni kurulan Millet Meclisi'nde yer aldılar. Dolayısıyla siyasi yapının birkaç kez kökten değiştiği çok uzun süreçte bile bu farklı yapıların bir parçası olmayı sürdürdüler. Avrupa örneğindeki gibi asilzâdeler sınıfına sahip olmadığı söylenen Osmanlı İmparatorluğu’nda Germiyanzâdelerin sürekliliği—bu makalenin doğrudan konusu olmamakla birlikte—-kendi başına bir araştırma konusu olmaya değer. ${ }^{17}$

Kütahya ve çevresi, 12. yüzyıl ve 15. yüzyıl arasında Bitinya sınır bölgesinin beyliklerin ekonomik, siyasi, sosyolojik ve kültürel dinamiklerini doğrudan belirlediği yüzyıllar sonrasında aynı dinamizme sahip olmamıştır. 14. yüzyılla beraber Osmanlı beyliğinin bir devlete doğru evrilmesi ve İstanbul'un fethi sonrasında imparatorluk kurumlarının yerleşmesiyle Kütahya, imparatorluğun bir iç-bölgesine dönüşmüş, çoğu zaman etrafındaki-bugünkü idari sınırlar ile

Roger Owen (eds.), (Carbondale and Edwards-Ville: Southern Illinois University Press, 1977), s. 27-52.

15 Khoury, "The Ottoman Centre," s. 136.

16 Germiyanoğlu Arif Hikmet Paşa için, bk. Nilüfer Bakan, "Salnamelere Göre Tanzimat'tan Cumhuriyet'e Kütahya Sancağı’nın Sosyo-Ekonomik Profili,” (Yüksek Lisans Tezi, Eskişehir Osmangazi Üniversitesi, 2007).

17 Yeni arşiv çalışmaları 15 ve 17. yüzyıllar arasındaki belge eksikliğini giderdiği takdirde bu tür uzun dönemli bir çalışma mümkün olabilecek ve benzer ailelerin tarihleri de karşılaştırılabilecektir. Bu türden bir örnek Heath Lowry’nin Evrenosoğulları üzerine yazdıklarında bulunabilir. Heath W. Lowry, The Nature of the Early Ottoman State (Albany: State University of New York Press, 2003), özellikle s. 55-94. 
belirtecek olursak-Ege ve Marmara bölgeleri ve Bursa, İzmir ve hatta Manisa ve Ankara gibi kentlerin sosyo-ekonomik etki alanının dışında kalmışır. Bu dönüşümde, meselâ, 16. ve 17. yüzyıllarda Bursa'nın, sonrasında İzmir' in ticaret ağlarını ya hemen kendi arka-bölgeleri ya da İç Anadolu yerine Marmara ve Ege havzası üzerinden genişletmiş olması etkili olmuştur. Ayrıca idari açından bakıldığında Anadolu eyaletinin paşa sancağı olarak kalsa da, 17. yüzyıldan sonra şehzadelerin artık sancağa çıkmaması bir şehzâde sancağı olan Kütahya’nın bu özelliğini de yitirmesine de yol açmıştır.

Bu uzun dönemli yaklaşımlar bir kenara bırakılırsa Germiyanzâdelerin 18 . yüzyılın son çeyreğindeki tarihi diğer pek çok ayanla benzerlik gösteriyor. Benzeri pek çok ayan gibi bu aile de değişen bir idarî yapı içinde tekrar yükseldiler ve servetlerini siyasi güce tahvil etmek için kullandılar. Kendi etki alanları olan Kütahya ve çevresinde bunu yaparken yine diğer ayanlar gibi farklı yollar izlediler. İdarî yapı içinde mütesellimlik gibi görevler aldılar. Devletin 17. yüzyıldan beri artan nakit ihtiyacı ile gittikçe monetize olan Osmanlı ekonomisi içinde borç para vermek ayanlar (ve elinde nakit parası olan diğer kesimler) için önemli bir fırsat sunuyordu. Böylelikle ilişki ağlarını genişletip, iktidarlarını sağlamlaştırabiliyorlardı. Buna benzer fırsatları kullandılarsa da Germiyanzâdeler hiçbir zaman çok büyük servet sahibi olamadılar. Etraflarında ördükleri alacak ilişkileri, örneğin Bursa’nın orta çaplı ayanları ya da tüccarları ile kıyaslanmayacak kadar sınırlı kaldı. ${ }^{18}$ Dolayısıyla, ne servetlerini ticaretten elde eden Bursa ayanları gibi borç vererek zenginleşmeye devam edemediler ne de Balkanlar ya da bazı Arap eyaletlerindeki gibi etraflarında kendilerine bağlı, silahlı bir kapıhalkı oluşturabildiler. Ayrıca, ayanların iktidarları için çok önemli bir rol oynayan mukata’alar söz olduğunda da Germiyanzâdelerin gücü sınırlı kaldı. Öyle anlaşılıyor ki, bölgelerindeki malikâne-mukata'alara ${ }^{19}$ sahip olamadılar, bu da siyasi güçlerini etkiledi. Karaosmanzâdeler gibi büyük ayan aileleri servetlerini-sınırlı da olsa—yatırım yaparak, vakıflar kurarak etkili oldukları bölgelerin altyapısını değiştirmek için kullanmaya çalışırken, Germiyanzâdelerin bölgelerinin sosyo-ekonomik yapısını doğrudan değiştirecek güçleri olmadı.

18 18. yüzyılda ve Bursa çevresinde zenginliğin ne anlama gelebileceği ve çok zengin olmayan ama varlıklı bir esnaf örneği üzerinden karşılaştırma için, Suraiya Faroqhi, "18. Yüzyıl Bure sa’sında Zengin Olmak: Debbağ Hacı İbrahim'in Serveti," Osmanlı Dünyasında Üretmek, Pazarlamak, Yaşamak, Toplumsal Tarih Araştırmaları, (İstanbul: Yapı Kredi Kültür Sanat Yayıncilık, 2008), s. 199-218.

19 Mehmet Genç, "Osmanlı Maliyesinde Malikane Sistemi," in Osmanlı Imparatorluğunda Devlet ve Ekonomi (İstanbul: Ötüken Neşriyat, 2000). Ariel Salzmann, "An Ancien Regime Revisited: Privatization and Political Economy in the 18th Century Ottoman Empire," Politics and Society 21/4 (1993). 
Bununla beraber Germiyanzâdeler 18. yüzyılın sonunda birden ortaya çıkmadılar. Batı Anadolu’daki Karaosmanzâdeler, Orta Anadolu'daki Çapanoğullar1 ya da Kuzey-Doğu Anadolu'daki Caniklizâdeler'in tersine Germiyanzâdelerin kökleri çok daha eskilere uzanıyordu. Büyük ayan aileleri hızla yükselip, kayda değer servet ve siyasi güç sahibi olduktan sonra İstanbul'a karşı koyacak gücü bile kendilerinde bulmuşlardı. Germiyanzâdeler ise çok daha yavaş yükseldiler, ama belki de bu yüzden güçlerini aniden ve tamamen yitirmediler.

Kendi bölgelerinin sosyo-ekonomik yapısı içinde büyük miktarlarda servet biriktiremeyen Germiyanzâdeler merkezî idarenin değişen idarî yapısı içinde ve 18. yüzyıl sonundaki Osmanlı-Rus savaşı döneminde, özellikle de 1787-1792 döneminde yükseldiler. Osmanlı devletinin savaş dönemindeki malî krizi, asker toplamadaki sıkıntısı, lojistik destek ihtiyacı ve başkentin—hiç bitmeyen ama savaş dönemlerinde daha da artan—iaşe endişesi Germiyanzâdelerin yerel güçlerini kullanmaları için bir dizi firsat sundu. Ama savaş döneminin sunduğu fırsatlar esas itibarıyla devletin ihtiyaçlarına bağlıydı ve bu durum aynı zamanda Germiyanzâdelerin gücünün sınırını oluşturuyordu. Yükselişleri de bu yüzden sınırlı oldu ve 19. yüzyılın başından itibaren yok olmasalar da tekrar gözden kayboldular.

Tabii kısa dönemli değişimlerin yanında daha uzun süreye yayılmış idarî uygulamalar da Germiyanzâdelerin güçlerini arttırmasının kanallarını açmıştı. 17. ve 18. yüzyıl boyunca farklı gelirler kaynaklarının arpalı $\mathrm{k}^{20}$ gibi uygulamalarla yönetici sınıf üyelerine dağıtılması aslında yeni bir himaye ağı oluşturmuştu. Kendilerine verilen kaynakları yerinden idare etmek ya da gelirleri kendileri toplamak yerine bu yönetici grup kaynakların idaresini genellikle yerel ayanlara bıraktı. Bu uygulama ise kaynakların tasarrufu üzerinde hak sahibi olanların sayısını arttırdı ve Hülya Canbakal'ın işaret ettiği gibi, meselâ eyalet valilerinin gelirleri gibi kaynaklar, yerel ayanların üzerinde hak sahibi olmak için rekabet ettikleri bir gelir havuzu oluşturdu. ${ }^{21}$ İşte Kütahya'da da 18 . yüzyıl sonu ve 19. yüzyıl başında mütesellimlik kurumu Germiyanzâdeler, Nasuhzâdeler ve Abbas Ağa’nın mücadele alanı oldu.

20 Arpalık için özellikle İnalcık, "Centralization and Decentralization in Ottoman Administi ration," s. 29.

21 Hülya Canbakal, 17. Yüzyılda Ayntâb Osmanlı Kentinde Toplum ve Siyaset, Zeynep Yelçe (çev.), (İstanbul: İletişim Yayınları, 2009). 


\section{Germiyanzâdeler}

$\mathrm{Bu}$ genel tarihî bağlam içerisinde bakıldığında 17. yüzyılın sonunda Germiyanzâdelerin siyasî ve idarî yapı içindeki konumları açı değil. 1699 şer'iyye sicillerinde, Germiyanzâde Mehmet Ağa’nın herhangi bir idarî ünvanı bulunmamaktadır. Yıldırım Bayezid vakfı ile ilgili bir davada adı sadece şahit olarak, herhangi bir ünvan olmaksızın geçiyor. ${ }^{22}$ Pek tabii ki -zâde eki kendi başına bir asâlet ünvanı, yine de Anadolu Valisinin huzuruna çağırıldığında kendisinden sadece "Kütahya sakini" olarak bahsediliyor. ${ }^{23}$

Ancak 1700 'den 18. yüzyılın ikinci yarısına kadar Germiyanzâdeleri belgelerde izlemek zorlaşıyor çünkü her şeyden önce 18. yüzyıl Kütahya sicillerinde yaklaşık 60 yıllık bir boşluk bulunmaktadır. ${ }^{24}$ Hiç şüphesiz bu boşluğu Mühimme Defterleri gibi diğer arşiv kaynakları ile bir dereceye kadar doldurmak mümkün olabilir. Yine de, özellikle tek bir ailenin tarihini takip etmek gerektiği zaman, iktisat tarihi açısından bu defterler siciller kadar bilgilendirici değil. Daha somut bir örnek vermek gerekirse, 17. yüzyıldaki Mühimme Defterlerinde Kütahya ve çevresindeki siyasi ve bazı sosyal gelişmeleri takip etmek mümkünse de Germiyanzâdeler hakkında doğrudan bilgiler çok sınırlıdır. Süleyman Polat'ın 17. yüzyılda 37 Mühimme defteri üzerinde yaptığı araştırmada Kütahya ve bölgesine gönderilen 179 hüküm tespit edilmiştir. Bunların yarıya yakını—72

22 Ekrem Güngör, "1 Numaralı Kütahya Şer’iyye Sicili (2. Bölüm) Transkripsiyonu ve Kritiği,” (Yüksek Lisans Tezi, Dumlupınar Üniversitesi, 2006.) [Bundan böyle: K2/sayfa numarası/ sicil kayıt numarası olarak gösterilecek, K2/82/424] Ancak sicillerde ya da diğer belgelerdeki ünvanları mutlak surette bir dönemin güç dengesinin işareti olarak görmemek gerekir. Aynı dönemde ve aynı konuyla ilgili olarak belgelerde bile daha önce ayan olarak tanınan ve tanımlanan bir kişi pekâlâ bir başka belgede "kasaba sükkanından" olarak tanımlanabilir. $\mathrm{Bu}$ ifadeler hiç şüphesiz rastgele kullanılmıyordu. Merkezi idarenin gözünden düşen bir ayanın tüm ünvanları bir kenara bırakılabilirdi. Bir mütesellimle bir mütegallibeyi ayıran çizgi çok da belirgin değildi. Tam da bu yüzden ünvanlardaki bu değişiklikleri doğru olarak değerlendirebilmek için belli bir bölgedeki tarihi koşulları ve dönüşümleri ayrıntılı olarak ortaya çıkarmak gerekir. Başka pek çok örnek yanında, bk. Anastasopoulos, "Lighting the Flame of Disorder: Ayan Infighting and State Intervention in Ottoman Karaferye, 1758-59," International Journal of Turkish Studies 8 (2002), özellikle, s. 75-80.

23 Güngör, "1 Numaralı Kütahya Şer’iyye Sicili (2. Bölüm) Transkripsiyonu ve Kritiği," $\mathrm{K} 2 / 113 / 570$.

24 Yücel Özkaya 1994 tarihli çalışması için şu notu veriyor; "Kütahya şer’iye sicilleri: 1 nolu şer'iyye sicil defteri 1700-1750 arası olayları alır, 2 nolu defter ise 1750 epey sonrası [sic] olayları alır ve sırayla devam eder." Özkaya’nın notuna göre kendisinin faydalandığı siciller araştırmasını yaptığı zaman Kütahya müzesindeymiş. Bu çalışma esnasında ise siciller Ankara’da Milli Kütüphanedeydi. Sicillerin mikrofilmlerine göre 1 numaralı Kütahya sicilleri 1697 - 1702 yıllarını kapsarken, 2 numaralı defter 1757-1760 yıllarını kapsıyor. 
tanesi-öncellikle eşkiyalar ve Celâlî ayaklanmaları ile ilgilidir. ${ }^{25}$ Germiyanzâde Yakub Çelebi vakfının tamiri gibi ailenin ekonomik kaynakları ile bilgi verebilecek bir veri isyanlar sonucu bakıma muhtaç olduğunu gösterse de diğer belgelerde doğrudan aile tarihi üzerine veri yoktur. ${ }^{26}$ Hal böyle olunca, 18. yüzyılın ilk yarısı için özellikle iktisadî serilere dayalı bir değerlendirme yapmak zordur.

Bu sorular ve sınırlamalarla beraber 1760 'lar ve 70 'lere gelindiğinde, ayanlık iddiası taşıyan ya da Kütahya ve çevresinde eşkiya olarak tanımlanan pek çok irili ufaklı kişi yanında, ${ }^{27}$ Germiyanzâde Hacı Yusuf Ağa Kütahya sicillerinde şehrin ileri gelenlerinden bir ayan olarak karşımıza çıkıyor. Hacı Yusuf Ağa’nın adı hem vakıflara ait önemli davalarda şahit ${ }^{28}$ olarak geçiyor hem de Kütahya ve çevresine gönderilen idarî emirler ve "tevzi' defterleri” nde. ${ }^{29} 18$. yüzyılda farklı bölgelerden alınacak yerel masraflardan menzillerin bakımına kadar pek çok harcama kalemi için uygulamaya konan "tevzi' defterleri” bir bakıma merkezî idare ile vilayetler arasındaki bir uzlaşmanın sonucuydu. ${ }^{30}$

25 Süleyman Polat, "17. Yüzyılda Mühimme Defterlerine Göre Kütahya," (Yüksek Lisans Tezi, Dumlupınar Üniversitesi, 2005).

26 Polat, "17. Yüzyılda Mühimme Defterlerine Göre Kütahya,” s. 68.

27 1760'da Gönen'de Sepetoğlu için Bkz. Başbakanlık Osmanlı Arşivi (BOA), Anadolu Ahkâm 35/952; 1765'de Seferihisar, Günyüzü'de voyvodanın tevzi' defterlerinde belirtilenden daha fazla vergi alarak yaptığı zulm için, Anadolu Ahkâm 48/592; 1766 ve 1768'de Şeyhlü'de Hacı Ali, Gökçe oğlu İbrahim’in 12.000 kuruşluk gasbı ve Kütahya züemâsında Arslanlığlu Osman ve adamları, ayanlık iddiasında olan Bosnabeyoğlu Hacı Ali için, BOA, Anadolu Ahkâm 55/43 - 388 - 513.

28 Şahitlerin rolü ve sosyal statüleri üzerine, bk. Canbakal, 17. Yüzyılda Ayntâb, özellikle 4. ve 5. bölümler. Ayrıca, bk. Boğaç Ergene, Local Court, Provincial Society and Justice in the Ottoman Empire: Legal Practice and Dispute Resolution in Çankırı and Kastamonu (16521744 ) (Leiden: E.J. Brill, 2003). Daha erken bir örnek için, Claude Cahen, "A Propos Des Shuhud," Studia Islamica, 31 (1970), s. 71 - 79

29 Kütahya Şer’iye Sicilleri, no.3 [Bundan böyle KŞS-3/sicil kayıt numarası olarak gösterilecek]: KŞS-3/22, (sicildeki 133 numaralı kayıttan sonra gelen kayıt, ancak numaralandırılmamış), 155, (165 numaradan sonraki kayıt; bu da numaralandırılmamış), 205, 258, 283. Ayrıca Yusuf Ağa miras (KŞS-3/278), tecavüz (KŞS-2/1) ya da mülk davalarında da (KŞS3/257) şahit olarak gözükmekte.

30 18. yüzyıl ve bu defterlerle ilgili olarak, Yavuz Cezar, "Comments on the Financial History of the Ottoman Provinces in the 18th Century: A Macro Analysis," Essays on Ottoman Civilization, Praha: Academy of Sciences of the Czech Republic Oriental Institute - Proceedings of the XIIth Congress of the CIEPO 1996, (Prague: Academy of Sciences of the Czech Republic, Oriental Institute, 1998), s. 85-92; Yavuz Cezar, "From Financial Crisis to the Structural Change: The Case of the Ottoman Empire in the Eighteenth Century," Oriente Moderno 18 (1999), s. 49-54. Rumeli vilayeti için, Gergana Georgieva, "Administrative 
Germiyanzâdelerin belgelerde görünür olması sadece bu defterlerle sınırlı değildi. Meselâ, aynı yıllarda Haremeyn Evkâfından Yakub Çelebi vakfının mütevellisi Germiyanzâde Yusuf Ağa, evkâf nazırları tarafından vakfın gelirlerini eksik göstererek zimmetine para geçirmekle ve evkâf görevlilerinin işlerini yapmasına engel olmakla itham edilir ve yerine Haremeyn Evkafindan bir başka mütevelli atanması önerilir. ${ }^{31} \mathrm{Bu}$ uyarılar çok da dikkate alınmaz ve 1780 'lerin ilk yılları Germiyanzâde Yusuf Ağa için bir dönüm noktası olur; 1781'de mütesellim olarak tayin edilir. Bu belgelerin içeriklerine uygun olarak da Yusuf Ağa önce ayan ve mütegallibe tanımlanırken, mütesellimlik beratında "hanedân-1 kadîm" olarak tanımlanır. ${ }^{32}$

Bu tür ifadeler hem beratların "resmî" diline hem de dönemin koşullarına uygun olarak ayanların meşruluğunu tanımlamak için sıkça kullanılsa da hanedanlık ifadesi aslına bakılırsa Germiyanzâdeler için sonradan icat edilmiş bir formül değildi. Meselâ III. Ahmed cülûsunda Kütahya'dan da hediyeler gönderilmiş, Germiyanzâdeler Kütahya'nın tek yerel ayanı olarak listede yer almış ve yine hanedan olarak tanımlanmışlardır. ${ }^{33}$ Ancak Germiyanzâdelerin yükselişleri, yeniden hanedân-1 kadîm olarak tanımlanmaya başlamaları ciddi bir siyasî mücadele alanı içinde ve diğer ayanlarla olan rekabetleri bağlamında değerlendirilmelidir.

Structure and Government of Rumelia in the Late Eighteenth and Early Nineteenth Centuries: The Functions and Activities of the Vali of Rumelia," Ottoman Rule and the Balkans, 1760-1850 Conflict, Transformation, Adaptation - Proceedings of an International Conference Held in Rethymno, Greece, 13-14 December 2003, Antonis Anastasopoulos ve Elias Kolovos, (eds.), (Rethymno: University of Crete Department of History and Archaeology, 2007), s. 3-20.

31 Kütahya Şer'iye Sicilleri, no. 4 (Bundan böyle KŞS-4/sicil kayıt numarası olarak gösterilecek), KŞS-4, 94, 184-185, KŞS-4/184'deki dava metninden “ ... vakf-1 mezbûr fazlası evlâd-1 mütevelliye meşrûta olmayub haremeyne haremeyn-i muhteremeyne aid olucak evkaf-ı kadimeden kesirü'l-irad ve vafîrü'l-kira ber cesim [?]-i vakf olub bu makule evkafin kaffe-i irâd ve masarıfı katib-i vakf kalemiyle zabt ve tahrir ve senesi hitamında irad ve masarıfât-1 sahihasını mübeyyin defter müfredatı kalemine teslim birle tekrar tedkik ve hulasa olundukdan sonra bâ-arz-ı nazır ve bâ-ferman- âlî i’tâ olunan suret-i muhasebesini haremeyn-i şerifeyn müfettişi ve muhasebecisi mühr ile temhir olunmak şurût-1 nizam-1 mer'iyyeden iken merkûm El-Hac Yusuf medine-i Kütahya’nın âyyân ve mütegallibesinden olmağla ketm-i irâd vakfa dair hilesine suret vermek içün...”

32 KŞS-4/199-200.

33 Cevdet Dadaş ve Atilla Batur, Osmanlı Arşivi Belgelerinde Kütahya 1 (Kütahya: Kütahya Belediyesi, Kütahya Kültür ve Tarihini Araştırma Merkezi Yayınları, 1999), I, Müteferrik, (no. 21). 


\section{Mütesellimlik İçin Rekabet:}

\section{Abbas Ağa, Nasuhzâdeler ve diğer bölge ayanları}

1781 ile 1820 arasında—diğer ayanlık durumlarında sıkça rastlandığı gibiGermiyanzâdeler özellikle mütesellimliği elde tutmaya çalışılar ve 1788'de Yusuf Ağa’nın oğlu Ali Ağa da mütesellim olur. ${ }^{34}$ Ancak ailenin mütesellimliği aralıksız olarak tutamadığı anlaşılmaktadır. Örneğin, 1783 ile 1786 arasında Kütahyàya giden belgelerde mütesellimliği en azından $1765^{\prime} \mathrm{e}^{35}$ kadar geri giden Abbas Ağa’nın adı vardır. ${ }^{36}$

Zaten 1790'ların başında katledilene kadar ${ }^{37}$ Abbas Ağa, Germiyanzâdelerin mütesellimlik için en büyük rakiplerinden biri olacaktır. Diğer pek çok ayan ve eşraf gibi Abbas Ağa da zaman zaman yolsuzluk ve zulmle suçlanmış, azl edilmiş, daha sonra yine mütesellim olarak tayin edilmiştir. Meselâ 1775 tarihli, Anadolu valisi Abdi Paşa’ya ve Kütahya kadısına gönderilen bir belgede, Abbas Ağa’nın Emir Hacı Mustafa adlı şahsı haksız yere katlettiği ve 15.000 kuruşuna el koyduğu bildirilir, ama buna rağmen zimmetindeki parayı geri verdiği takdirde affedileceği de eklenir. ${ }^{38} 18$. yüzyılın sonunda devletin karşı karşıya kaldığı nakit para sıkıntısı, asker toplamada ve lojistikteki sorunları çoğu zaman mütegallibe olarak adlandırdığı kişileri idarî mekanizmanın içinde tutmasına yol açmıştı. Hemen her düzeydeki kaynakların kullanılabilmesi için ara-kadrolar olarak görülebilecek ayan ve eşraf yerel kaynakların harekete geçirilmesinde en önemli yeri tutuyorlardı. Gerek Arap topraklarında, gerekse Balkanlarda ayanların bu arabulucu rolü ve yerel unsurları temsil etme gücü zaten pek çok tarihçinin işaret ettiği bir husus olmuştur. ${ }^{39}$

Ayrıca 18. yüzyılın sonunda geçerli genel koşullar kadar, kişisel ilişkiler de iktidarın yerel düzeyde nasıl kazanıldığı ve sürdürüldüğü hakkında dikkate alınmalıdır. Bu konuda Abbas Ağa’nın şahsi bağlantıları bazı fikirler verebilir. Koca

34 BOA, Cevdet Dahiliye 7340.

35 Firar eden şaki Gönenli Sepetoğlu Osman Ağa’nın zabt edilen mallarının muhallefatında,

"Osman Ağa’nın deve bahasından ve Bursa mukataası malından Kütahya mütesellimi Abbas

Ağa’ya bâ-temessük 500 kuruşzimmeti olduğu sabit olduğu” üzere, BOA, Cevdet Zaptiye 2477.

36 BOA Cevdet Zaptiye 3519; Cevdet Maliye 27165; BOA, Anadolu Ahkam 85/484.

37 Abbas Ağa’nın katli sonrası hazırlanan muhallefat defteri 1792 tarihlidir, bk. BOA, Baş Muhasebe Muhallefat, (D. BŞM. MHF) 12993.

38 BOA, Cevdet Dahiliye 9995.

39 Artık klasik olmuş bir örnek, Albert Hourani, "Ottoman Reform and the Politics of Notables, "Beginnings of Modernization in the Middle East, William R Polk, Richard Chambers (eds.), (Chicago: The University of Chicago Press, 1968), s. 41-68. 
(ya da Büyük) Abdi Paşa’nın ${ }^{40} 1775$ ve 1781 yıllarına denk gelen Kütahya valiliği hem Germiyanzâdeler hem de Abbas Ağa için belirleyici olmuştur. Örneğin, 1781'deki görevine gelmeden önce Germiyanzâde Yusuf mütesellimlik yaparken, ${ }^{41}$ Abdi Paşånın avdetinden sonra Abbas Ağa mütesellim olarak tayin edilir. ${ }^{42}$ Abdi Paşa ve Abbas Ağa ilişkisinin belki de en önemli kanıtı, Abdi Paşa’nın ölümünden sonra kılı kırk yaran müsadere sürecinde Abbas Ağa’nın hemen her tür belgede ortaya çıkmasıdır. ${ }^{43}$ Hatta Paşa’nın Kütahya'daki mülkleri ve çiftliğinin ilk muhallefat defteri hazırlandıktan sonra ortaya çıkan sonuç şüphe uyandırır. Yapılan araştırma sonucunda mübaşirin, Abbas Ağa’nın da yardımıyla, bazı malları sakladığı düşünülür. Dolayısıyla merkezden gönderilen ilgili hatt-1 hümâyûnlarda Abdi Paşa’nın elmas ve yakut yüzüklerine varıncaya kadar ortaya çıkarılması gerektiğini özellikle belirtilir. ${ }^{44}$ Abbas Ağa azl edilir ama bu kez de Abdi Paşa’nın yeni bir muhallefatının hazırlanması için iş birliği yapınca herhalde daha büyük bir cezadan kurtulur. ${ }^{45}$

Abbas Ağadan sonra bu kez Germiyanzâde Yusuf Ağa’nın oğlu, Hacı Ali Ağa, mütesellim olarak tayin edilse de bu uzun süreli olmaz. ${ }^{46}$ Ali Ağa Eflâk seferine katılmak için kendisine tahsis edilen 17.000 kuruşa yakın para ile firar eder ve bunun üzerine Kütahya'daki mallarına da akrabaları el koyar. Merkez de 1790 yılında Hacı Ali Ağa’nın mallarının müsadere edilmesi ve gerekirse kendisinin katledilmesi için ilgili emri derhal gönderir. ${ }^{47}$ Ali Ağa’nın Eflâk seferine gitmekten kaçınması ve belgenin diliyle "firar" etmesi herhalde sadece Ali Ağa’nın firsatçılığına bağlanamaz. Bu aynı zamanda Germiyanzâdelerin kendi etraflarında yeteri kadar asker toplamayamadıklarını gösterir ve bölgedeki güçlerinin de sınırlı olduğunu düşündürür. Ayanların etraflarında topladıkları askerî güçlerle

40 Bkz, Mehmed Süreyya, Sicill-i Osmanî, Nuri Akbayar, (ed.), (İstanbul: Tarih Vakfı Yurt Yayınlar1, 1996), I, s.53.

41 Teftiş-i saray buyuruldusunda, Germiyanzâde Yusuf'un Vali Abdi Paşa’nın sarayında gerekli onarımları yapması istenir, KŞS/4-203.

421783 ve 1786 yılları ahkâm defteri kayıtlarında Abbas Ağa’nın mütesellim olduğu açıktır. BOA, Anadolu Ahkâm 87/99, 89/650, 91/825.

43 Abdi Paşa'nın Kütahya'daki yatırımları kendi başına bir çalışma konusu olabilir. Bu konudaki bazı belgeler, BOA, Hatt-1 Hümâyûn (HH) 6471; 9453; 9724; 9752; 10114; 11233; 11555; 16102; 11625 ve BOA, Cevdet Maliye 4964; 23728.

44 BOA, Hatt-1 Hümâyûn (HH) 9453.

45 BOA, Hatt-1 Hümâyûn (HH) 11233.

46 BOA, Cevdet Dahiliye 7340.

47 Başbakanlık Osmanlı Arşivi (BOA), Hatt-1 Hümâyûn (HH) 55212. 
(kapılı leventler, sekban ve sarıcalarla) savaşa katılmalarının gittikçe önemli olmaya başladığ $1^{48}$ bir dönemde böyle bir firsatı kaçırmak çok da akıllıca değildir. Bunu yapabilmek için sadece güçlü ekonomik ve siyasi ilişkiler ağı kurmuş olmak yetmez, bunu askeri güce çevirebilmek de gerekir. Ya da zaman zaman şiddet kullanarak, ayanlar-gittikçe genişletmek eğiliminde oldukları—bölgelerinde ekonomik zenginliklerinin temellerini atarlar. Dolayısıyla, doğrudan katkılarının arandığı her askeri hareketlilik ayanların güçlerini sürekli kılabilmek için bir fırsat doğurur. ${ }^{49}$

Rakibi Ali Ağa’nın gözden düşmesiyle, beklenebileceği gibi, Abbas Ağa tekrar mütesellimliği alır. Ancak, bu kez de Abbas Ağa’nın mütesellimliği kısa sürer ve 1791 'de Germiyanzâde Süleyman Ağa mütesellim tayin edilir. Bu tayin dolayısıyla Kütahya ileri gelenlerinin yazdığı bir arîzada Süleyman Ağa’nın (ya da daha doğru olarak Germiyanzâdelerin) Kütahya’nın eski "hanedanlarından" olduğu ve en az otuz yıldır mütesellimlik görevini ifâ ettiği bildirilir. Arîza aynı zamanda—büyük bir olasılıkla Abbas Ağa yerine tayin edilmiş_Hacı Molla’nın kısa zamanda yapmaya başladığı yolsuzluk ve fesattan şikâyet etmektedir. ${ }^{50} \mathrm{Bu}$ dönemde çok sık değişen yerel idari görevler mütesellimlik makamının nasıl ve hangi sırayla el değiştirdiğini kronolojik bir kesinlikle takip etmeyi zorlaştırsa da, Kütahya ve çevresindeki eşraf ve ayanlar arasında ilişkiler ağının nasıl örüldüğü hakkında bir fikir sahibi olmak mümkündür.

48 Genel bir değerlendirme için bk. Virginia Aksan, Ottoman Wars 1700-1870 an Empire Besieged (London: Pearson, 2007). Virginia Aksan, Ottomans and Europeans: Contacts and Conflicts, (İstanbul: The ISIS Press, 2004), özellikle 2. bölüm içinde 2. 3. ve 5. makaleler; sirasiyla, "The One-Eyed Fighting the Blind: Mobilization, Supply and Command in the Russo-Turkish War of 1768-1808," s. 170-190; “Ottoman Military Recruitment Strategies in the Late Eighteenth Century," s. 191-208; "Whatever Happened to the Janissaries? Mobilization for the 1768-1774 Russo-Ottoman War.” s. 209-222.

$49 \mathrm{Bu}$ açıdan bakıldığında Yanyalı Ali Paşa ile bir karşılaştırma ayanlar arasındaki farkı ortaya koyması açısından çok açıktır, bk. Dimitris Dimitropoulos, "Aspects of the Working of the Fiscal Machinery in the Areas Ruled by Ali Paşa," Ottoman Rule and the Balkans, 1760-1850 Conflict, Transformation, Adaptation - Proceedings of an International Conference Held in Rethymno, Greece, 13-14 December 2003, s. 61-72. Antonis Anastasopoulos, Elias Kolovos, (eds.), (Rethymno: University of Crete Department of History and Archaeology, 2007), s. 61-72 ve K. E. Fleming, The Muslim Bonaparte Diplomacy and Orientalism in Ali Pasha's Greece (Princeton, New Jersey: Princeton Modern Greek Studies, Princeton University Press, 1999). Bir başka karşılaştırma için, Meryem Kaçan Erdoğan, Meral Bayrak Ferlibaş ve Kamil Çolak, Tirsiniklizâde İsmail Ağa ve Dönemi (1796-1806), (İstanbul : Yeditepe Yayınevi, 2009).

50 BOA, Hatt-1 Hümâyûn (HH) 1973. 
Germiyanzâdeler ve Abbas Ağa rekabetinin yanında Kütahyảyı da içine alan biraz daha büyük bir bölgede, büyüklü küçüklü başka rakipler de vardır. Bilecikli Hacı Himmetoğlu, ${ }^{51}$ Eskişehirli Tiryakioğlu Ömer, ${ }^{52}$ Mihaliç voyvodası Çıracıoğlu Mustafa ${ }^{53}$ gibi kimseler de merkezi idare ile benzer ilişkiler kurarlar. 1790 ile 1810 arasında yoğunlaşan bu ilişkiler ağındaki grubun servetleri çoğunlukla 1790 'lardan sonra müsadere edilir. Ama müsadere süreci de hiçbir zaman mutlak bir yol izlemez ve ayan aileleri ile pazarlık hep devreye girer. ${ }^{54}$ Meselâ Eskişehir ayanlarından Tiryakioğlu Ömer de Germiyanzâde Ali Ağa gibi, kendisine üçyüz nefer toplamak için tahsis edilen yaklaşı 17.000 kuruşla seferden firar edince, bunun bedeli sonunda ortadan kaldırılması ve benzer durumlarda olduğu gibi servetinin müsaderesi olur. Hazırlanan defterde Tiryakioğlu'nun serveti 9.000 kuruşu bulur ve bunun üzerine Tiryakioğlu'nun iki eşi İstanbul'a müsaderenin affı için başvurur ve bunda başarılı olurlar. ${ }^{55}$ Müsaderenin uygulanmamasında büyük bir olasılıkla yerel ayanı-daha doğrusu Tiryakioğlu'nun durumunda olduğu gibi, ailesini-güçsüz bırakmamak ve dolayısıyla yeniden başvurulacak bir aracıyı tamamen ortadan kaldırmamak gibi bir dikkat ve çekince de rol oynamış olsa gerek.

Ancak, henüz 1760 'da hakkında zulm ve teaddi şikayetleri yapılan, ${ }^{56} 1765$ ve 1779 yılları arasında Gönen, Manyas ve Kütahya ayanı olarak anılan Sepetoğlu Osman için İstanbul bu kadar hoşgörülü davranmamıştır. ${ }^{57}$ Sepetoğlu da hem iltizam sahibi olmuş hem de sefer firarisi durumuna düşmüştü. Bunun üzerine hazırlanan defterlerden anlaşıldığı kadarıyla birkaç çiftliği vardı ve hayvancılık da yapıyordu (bunların arasında 300 civarında devesinin olması dönem ve bölge için

51 BOA, Cevdet Maliye 4371.

52 BOA, Cevdet Maliye 5052.

53 BOA, Cevdet Maliye 2051; 26880.

54 Müsaderenin bir Osmanlılık kimliğinin, daha somut olarak söylemek gerekirse, yönetici seçkinler grubunun bir parçası olmanın göstergesi olduğu fikri için, Karl Barbir, "One Marker of Ottomanism: Confiscation of Ottoman Officials' Estates," Identity and Identity Formation in the Ottoman World, a Volume of Essays in Honor of Norman Itzkowitz, Baki Tezcan, Karl K. Barbir Madison, (eds.), (Wisconsin: The Center for Turkish Studies at the University of Wisconsin and The University of Wisconsin Press, 2007), s. 135-146. Aynı dönemde Bursa örneği ile karşılaştırmak için, Nilüfer Alkan Günay, "Müsaderenin Sosyal ve Ekonomik Bir Analizi: 18. Yüzyıl Sonlarında Bursa'da Yapılan Müsadereler,” Belleten, 76 (2012), s. 793-817.

55 BOA, Cevdet Maliye 5052.

56 BOA, Anadolu Ahkâm 35/952.

57 BOA, Baş Muhasebe Muhallefat, (D. BŞM.MHF) 12701; 12856, BOA, Cevdet Zaptiye 2477, Cevdet Maliye 6910; 7359, Cevdet Adliye 3650. 
önemli olan taşımacılığa da yatırım yaptığını gösterir). Aynı zamanda dokuz da kölesi vardı. Benzer ayanlar gibi borç ilişkileri geniş değildi ama Abbas Ağa’ya 500 kuruş borcu olması, her ikisi arasındaki ilişkinin sadece sosyal ya da siyasî olmadığını gösterir. Sonuç olarak müsadere uygulanmış ve İstanbul'a 70.000 kuruşluk bir meblağ gönderilmişti ki bölge söz konusu olduğunda bu yüksek bir meblağ sayılabilir.

Sepetoğlu ile kıyaslandığında, başka bir ayanın, Himmetoğlu’nun iktidarını nasıl sağladığı ve idame ettirdiği görece küçük bir bölgede bile ayanlar ve ayanlık stratejileri arasında ne tür farklılıklar olabileceğine iyi bir örnektir. Kütahya mütesellimine Bilecikli Himmetoğlu Ahmed için henüz 1776'da gönderilen bir emirde Himmetoğlu'nun nakibül-eşraf Ahmed Şahzâde Halil Efendi'yi katlettiği, evini basıp, mallarına ve zimmet defterlerine el koyduğu bildirilir ve yakalanıp Anadolu Divânına çıkarılması istenir. Himmetoğlu adamlarıyla birlikte uzun bir süredir Bursa ve Kütahya arasında "geşt ü güzar" ve "katl-i nüfus" etmekte, doğal olarak da mütegallibeden sayılmaktadır. ${ }^{58}$ Ama yakalanması ve cezalandırılması mümkün olmamış olmalı ki 1786'daki bir başka emirde kendisi Bilecik ayanı olarak anılmaktadır. ${ }^{59}$ En nihayetinde, 1789 'da Himmetoğlu ve adamları katledilir ve kesik başları İstanbul'a gönderilir. Bunların mallarının müsaderesi için gerekli muhallefat defterini ise Abbas Ağa hazırlar. Himmetoğlu'nun durumundaki farklılık, diğer ayanlara kıyasla, çok daha geniş bir kredi ilişkileri ağı kurmuş olmasıdır. Hazırlanan deftere göre farklı borç ilişkilerinden oluşmuş bu meblağ 131.803 kuruşdur. ${ }^{60}$ Bilecik ve yakın çevresine dağılmış bu kadar büyük bir meblağın hemen toplanması hem zor olacağı hem de özellikle köylüleri zor duruma düşüreceği için, bazı köy ahalisi borçlarının 31.803 kuruşunun affedilmesi için arzuhal gönderirler. Farklı seçenekler üzerinde durulduktan sonra 50.000 kuruş toplanır, kalan 70.000 kuruşun iki taksitte ödenmesine karar verilir ve sadece 11.803 kuruşluk bir meblağ affedilir. ${ }^{61} \mathrm{Bu}$ karar ne borç ödemelerinin ne de Himmetoğlu' nun adamlarının sonu olur; malî ve siyasî takip 1805 'e kadar devam eder. 1790'dan bir yıl kadar sonra Anadolu Valisi ve Bilecik kadısına borçların 31.500 kuruşunun ödenmesi gerektiği ve fakat köylülerin sadece 20.000 kuruş ödeyebildiği bildirilir. Geri kalan 11.500 kuruşu ödemek için bir sarraf_herhalde daha sonra faiziyle

58 BOA, Cevdet Adliye 1523.

59 Kütahya Şer'iye Sicilleri, no. 5 (Bundan böyle KŞS-5/sicil kayıt numarası olarak gösterilecek), KŞS-5/128 Burada bile söz konusu olan Himmetoğlu’nun Mehmet Paşa evkafı mukaatasına "fuzulî müdahalesinin" engellemesidir.

60 BOA, Cevdet Maliye 11880.

$61 \mathrm{Bu}$ seçenekleri karşılaştırmak için: BOA, Cevdet Maliye 11880 ve BOA, Hatt-1 Hümâyûn (HH) 10292. 
daha yüksek bir meblağ geri almak için—devreye girse de, fikrini değiştirmesi ile, köylülerin geri kalan 11.500 kuruşu da acilen ödemesi istenir. ${ }^{62}$ Himmetoğlu’nun adamlarına gelince, onların da takibatı devam eder. 1805 'de yılında bile bir kısmı cezalandırılarak kesik başları İstanbul'a gönderilir. ${ }^{63}$

Himmetoğlu'nun tedîbi Abbas Ağa'nın son görevi olur. Zaten bir süredir hakkında "zulm" ve "teaddi" yaptığına dair bilgi ve şikâyetler İstanbul'a ulaşmaktadır. İstanbul'a ihzârı söz konusu olduğunda çevresindekileri mütesellim olarak kalması için arzuhal yazmaları yönünde ikna etmeye çalışır. Bu da yetmezmiş gibi, yerine atanan İsmail Ağa’nın ${ }^{64}$ rızası olmadan Kütahya ve çevresinden 12.500 kuruşluk yeni bir masraf toplamaya çalışır ve Himmetoğlu'nun bazı adamlarını da onlardan daha fazla para almak için hapseder. ${ }^{65}$ Bütün bunlar bardağ son damlalar olmalı ki Abbas Ağa 1792'den sonra Germiyanzâdelerin rakibi olmaktan tamamen çıkar; mütegallibe olarak tanımlanan diğer pek çok ayan ya da bürokrat gibi katledilir, ve yine benzeri durumlarda olduğu gibi emlâkı, malları ve hayvanları — hatta adamlarına bile ait olan at ve katırları—müsadere edilir. ${ }^{66}$ Ayrıca borçlarının da tahsil edilmesi için harekete geçilir. ${ }^{67}$

Fırsatını bulunca, Germiyanzâdeler güçlerini-ne kadar sınırlı da olsa-yeniden elde etmeye girişirler. Anadolu Valisi Ali Paşa'nın 1793'de Divân-1 Hümâyûn'a gönderdiği bir tahrirâtta, vefat eden Ömer Paşa'nın Kütahya'da bulunan ve eşi ile kızlarına ait olması gereken emlâkını Germiyanzâde Ali Ağa, Mustafa Ağa ve kethüdaları Hacı Mehmed'in "fuzûli zabt" ettikleri bildirilir. ${ }^{68}$ Yine de, 1794 'de yeni vali Abdullah Paşa, Germiyanzâde Ali Ağa’yı mütesellim tayin eder. ${ }^{69}$ İmparatorluğun malî ve askerî açıdan en sıkışık durumda olduğu bu yıllarda ayanların yerel düzeyde oynadıkları roller öyle çeşitli ve işlevseldi ki merkezî idare açısından ayanlara karşı atılan adımlar ince elenip sık dokunmak zorundaydı. Ayanlar idarî bir rol oynuyorlar, malî işlevleri yerine getiriyorlar, ordu için hem asker hem de erzak sağlıyorlar, ayaklanan unsurları bastırıp, gerekirse diğer ayanlara karşı da savaşıyorlardı. Bunların dışında başka işlevleri de vardı. Meselâ, 1795'de çok kötü durumda olan Yıldırım Bayezid vakfının tamiratı için gerekli olan 10.000 kuruşa

62 BOA, Cevdet Maliye 4371.

63 BOA, Hatt-1 Hümâyûn (HH) 14802.

64 Abbas Ağa’nın azli ve yerine İsmail Ağa’nın tayin edilmesi için, BOA, Hatt-1 Hümâyûn (HH) 9705.

65 BOA, Hatt-1 Hümâyûn (HH) 9836; 9752.

66 BOA, Cevdet Maliye 3418; 2034; 18095; Cevdet Adliye 3637.

67 BOA, Cevdet Maliye 6941.

68 BOA, Cevdet Maliye 21900.

69 BOA, Cevdet Dahiliye 9899. 
yakın meblağı vakıf karşılayamayacağı için Ali Ağa devreye girer ve bu belki de kendisine yeni bir mütesellimlik dönemi açar. ${ }^{70}$ Ancak bu da uzun sürmeyecek ve en sonunda 1802'de son bir kez mütesellim olduktan sonra Germiyanzâde Ali Ağa ortadan kaldırılacaktır.

Abbas Ağa’nın rekabeti ortadan kalktıktan sonra Germiyanzâdeler'in gücünü sınırlayan bir başka unsur yeni bir rakibin varlığıdır: Emet ayanlarından Nasuhzâdeler. ${ }^{71} 1780$ 'de Gedüs sakini olarak adı geçen Nasuhzâdeler, 1782 ahkâm defterlerinde derebey olarak anılır. Kütahya kadısı ve mütesellimine gönderilen bir hükümde Nasuhoğlu Ali, oğulları ve adamlarının uzun bir süredir mütegallibeden olup Uşak, Gedüs ve civarında "katl-i nüfus" ve "gasb-1 emvâl" ettikleri, son olarak da bedeli 50.000 kuruştan fazla mal ve tarımsal ürünü gasp ettikleri için Kütahya’ya getirilmeleri ve kendilerinden şikayetçi olanlar huzurunda yargılanmaları emrediliyordu. Bu hükümde daha önemli olan bir tespit Nasuhoğlu'nun esas niyetinin ayanlık ya da voyvodalık olduğu, bu niyetle etrafına adam topladığıdır. ${ }^{72}$ Benzer durumlarda olduğu gibi bu hükümlerin uygulanıp uygulanmadığını, ya da nasıl, ne koşullarda ve kimler tarafından uygunlandığını takip etmek tarihçi için kolay değildir. Ancak Nasuhoğlu (Koca) Ali 1795 'te öldüğüne göre şikayetlerden sonra uzun bir süre daha bölgede varlığını sürdürmüş olmalıdır. Ölümünden sonra sebebini bilmediğimiz bir gerekçeyle malları müsadere edilmiştir. Hazırlanan müfredat defterinde bazı çarpıcı bilgiler vardır: Nasuhoğlu Ali, Emet ve civarında zenginleşmiştir. Emet'te 1.000 kuruşluk küçük bir han, bir bağhane, bir değirmen yanında eşleri için ayrı bir ev sahibi olduğu anlaşllıyor. Ayrıca çok sayıda büyük ve küçükbaş hayvan yanında da farklı köylerdeki ambarlarda tahıl depolamıştır. Bu defter Nasuhoğlu Ali'nin küçük bir ayan olarak kendi sınırlı çevresinde tarımsal üretim üzerinden zenginleştiğini gösteriyor. Yine, defterde borç-alacak ilişkileri hakkında bilgi olmaması özellikle çevre şehirlerle de ticaret ve kredi ilişkilerinin sınırlı olduğunu düşündürüyor. ${ }^{73}$

Ama bu müfredat defteri yeterli olmaz ve defterin yeterliliğinden şüphelenen merkezî idare yeni bir inceleme yapılmasını gerekli görür. ${ }^{74}$ İlk yapılan tahrirata göre 15.971 kuruş emlâk, hayvanat ve diğer eşyalarından, 7.527 kuruş ise tahıl ambarlarından olmak üzere Nasuhoğlu'nun serveti 23.498 kuruş

70 BOA, Cevdet Evkâf 2380.

71 Uşak ayanları olarak da anılıyorlardı, Özkaya, Osmanlı İmparatorluğu’nda Ayanlık. s. 138, 167.

72 BOA, Anadolu Ahkâm 85/188.

73 BOA, Cevdet Adliye 3660; Cevdet Maliye 1198.

74 BOA, Cevdet Maliye 2271. 
tutmuştur. Ancak Gedüs, Simav ve Dağardı gibi Kütahya kazalarında iltizam sahibi olan Nasuhoğlu'nun daha fazla serveti olduğu ve ailesinin servetinin bir kısmını sakladığı düşünülmektedir. İkinci bir tahrirat zannedildiği gibi büyük bir servet ortaya çıkarmaz ve ilk müfredat defterine sadece 2.500 kuruş eklenir. Bundan sonra ise müteveffa Nasuhoğlu'nun 17 "nefer evlâdı" olduğundan ve beldelerinin de tarıma elverişli olmadığından bahisle varisleri muhallefatın kendilerine bırakılmasını arzuhallerinde bildirirler. En nihayetinde varılan sonuç 30.000 kuruş karşılığında servetin Nasuhoğullarına bırakılması olur. Ödeme de 10.000 kuruşu peşin, kalanı ise taksitler halinde İrâd-ı Cedîd hazinesine ödenmek üzere yapılacaktır.

İlk bakışta merkezi idarenin kârlı çıktığı gibi gözüken bu anlaşma Nasuhoğulları için de tamamen zarar hanesine yazılmaz çünkü 1797'de Ali Ağanın oğullarından Nasuh Ağa Kütahya mütesellimi tayin edilir. İlk işlerinden biri de Uşak ve civarında—daha önce kendilerinin de tanımlandığı gibi- "katl-i nüfûs" ve "gasb-1 emvâl" eyleyen mütegallibeden Acemoğlu Ahmed, Teslimoğlu Ömer ve adamlarını yakalayıp, kesik başlarını İstanbul'a göndermek olur ve bu iş için kendisine—geri verilmek üzere—bir top ve humbara bile zimmetlenir. ${ }^{75} \mathrm{Bu}$ açıdan bakıldığında muhallefat değerinden yüksek bir meblağı taahhüt etmek, Nasuhoğulları için bölgedeki siyasi sermayelerini korumalarının ve iktidarlarını biraz daha farklı bir biçimde devam ettirmelerinin yolunu açmıştır.

Ayanlar arasındaki ilişkilerin ve rekabetin—aynen merkezî idare ile olduğu gibi-sadece karşıtlık ve mücadele üzerine kurulu olmadığını belirtmek gerekir. Çok boyutlu bu ilişkiler ağı aynı zamanda ortak çıkarlar ve işbirliği üzerine kuruluydu. Bunun bir örneği eski Anadolu valisi Ali Paşa'nın Kütahya'daki iki çiftliğinin satışında görülür. Ali Paşa’nın vefatından sonra senelik 7.500 kuruş hasılatı olan iki çiftliği, elde edilecek miktar hazine-i amireye gönderilmek üzere, "müzayedeye" çıkarılır. Ancak iki hafta geçmesine ve (tarla ve hayvanların ayrı ayrı satılması gibi) farklı yollar denenmesine rağmen alıcı çıkmaz. Çiftliklerin değerinin 30.000 kuruşdan fazla olması müzayedeyi hiç şüphesiz zorlaştırmıştır. Sonuçta Nasuhzâdeler ve Germiyanzâdeler "ber vech-i iştirak" bu çiftlikleri almak için başvururlar ve peşin ödemek koşuluyla "mülknâme-yi hümâyûnun" kendilerine verilmesine karar verilir. ${ }^{76} \mathrm{Bu}$ yatırımla ne yaptıklarını ya da bunun tek ortaklıkları olup olmadığını bilmek mümkün değil, ama mütesellimliğin aralarında el değiştirdiğini söylemek mümkün.

75 BOA, Cevdet Zaptiye 3094.

76 BOA, Cevdet Maliye 13741. 
1799'da Vali Ebubekir Paşa, Nasuh Ağa'yı bir kez daha mütesellim tayin eder, ${ }^{77}$ ama bu sefer Nasuh Ağa görevi alır almaz, Dersaadet'e kendisinden, adamlarından ve zulümlerinden şikâyet eden arzuhaller de gitmeye başlar. ${ }^{78} \mathrm{Bu}$ şikayetler karşılık bulmuşa benzemiyor çünkü Nasuh Ağa göreve devam eder. Örneğin, 1800 'de kendisine gönderilen bir emirde bölgede ayanlık iddiası ile ortaya çıan Mustafa oğlu Hüseyin adlı şakinin üzerine gitmesi istenir. ${ }^{79} \mathrm{Bu}$ dönemde, Nasuh Ağa’ya gönderilen bir emirden Germiyanzâdelerin İstanbul'a uzanan mali ağların da içinde olduğu anlaşılır; Germiyanzâde Ali Ağa 1786 'da Galata voyvodası ElHac Mehmed Ağa'dan 35.000 kuruş borç almıştır. Sorun o ki borcunu ödememekte ve hep geciktirmektedir. Nasuh Ağa’nın görevi ise bu borcun tamamen tahsili ve eğer bu mümkün olmazsa Ali Ağa’yı mahkeme edilmek üzere İstanbul'a göndermektir. ${ }^{80}$

Ali Ağa’nın borcunu ödeyip ödemediği ya da Dersaadet'e gönderilip gönderilmediği açı değil, ama Germiyanzâdeler başka amaçlarla da İstanbul'a gitmişler. Sinop kadısına gönderilen ve aslında içeriği pek de açık olmayan bir emirde Germiyanzâde Mehmet'le beraber hisar kethüdasının ve başka birinin İstanbul'a gelip giderek bugünkü anlamıyla neredeyse kulis yaptıkları anlaşılıyor. Bu siyasi faaliyet geri tepmiş olmalı ki yaptıkları hem uygunsuz (bazılar haklarında nâhemvâr kelimât tefevvühüne ibtidâr) hem de düzeni bozacak kadar tehlikeli bulunur, dolayısıyla Sinop’a sürgün edilmeleri için ferman çıkar. ${ }^{81}$ Hükmün içeriğinden kimlerin hakkında konuşulduğu ya da neler söylendiği anlaşılmıyor. Sinop sürgününün hangi koşullarda ve ne kadar süreceği de belirsiz ama bu belirsizliklere rağmen ortada mütesellimlik için bir mücadele olduğunu, Germiyanzâde Mehmet ve yanındakilerin de bu yüzden İstanbul'da olduklarını düşünmek çok yanıltıcı olmaz. Birkaç sene sonra, 1802'de, Anadolu Eyaleti uhdesine arpalık olarak verilmiş olan Seyyid Mustafa Paşa döneminde, Germiyanzâde Ali, Nasuh Ağa’nın yerine bir kez daha tayin edilir. ${ }^{82}$

Nasuh Ağa’nın mütesellimliği kaybetmesi tabii ki siyasi-ekonomik gücünü kaybetmesi anlamına gelmiyordu. Nasuh Ağa siyasi gücünü arttırmak için borç vererek ilişki ağını genişletmemiş olsa da ailesinin diğer fertleri ve çocukları

77 BOA, Cevdet Dahiliye 57.

78 BOA, Cevdet Dahiliye 5160.

79 BOA, Anadolu Ahkâm 127/459.

80 BOA, Cevdet Adliye 2407.

81 BOA, Cevdet Zaptiye 586.

82 Ö. Kürşad Karacagil, “6 Numaralı Kütahya Şer’iye Sicili Transkripsiyonu ve Edisyon Kritiği” (Yüksek Lisans Tezi, Dumlupınar Üniversitesi, 2002). (K6/6) Nasuh Ağa’nın azlinin nedeni Kütahya halkıyla bir türlü anlaşamamasıdır ('adem-i imtizac). 
bu yola başvurmuşa benzer. Belki de bu yeni kuşakların daha önce biriktirilmiş olan sermayelerini arttırmak için başvurdukları bilinçli bir stratejiydi. Örneğin, 1815'de Tavşanlı sakinlerinin Nasuhoğlu Hacı İbrahim'in zulmünden yakındıkları bir arzuhalden ${ }^{83}$ anlaşıldığı kadarıyla Hacı İbrahim 1800 'lerin ilk yıllarından beri yüksek faizle borç veriyor ve bölge sakinlerinin çoğunu bu yolla kendisine bağlı hale getiriyordu. Merkezî idarenin buna cevabı ise Nasuhoğlu'nu doğrudan cezalandırmak yerine faiz oranının yüzde on olduğunu ve eğer daha fazla alınır ise, bunun geri verilmesi gerektiğini belirtmek olur. ${ }^{84}$ Borç faizlerini düzenlemek merkezî idarenin uygulamalarından sadece biridir, ayanlar siyaseti ise çoğu zaman daha kesin önlemlere başvurmayı gerektirir. Bunun da en açık kanıtı Nasuh Ağa’nın 1818'de ortadan kaldırılmasıdır.

Nasuh Ağa sonunun yakın olduğunu gördüğü için affedilmek ve yeniden itibar kazanmak için elinden geleni yapar gönderdiği bir arîzada devlete ne kadar sadık olduğunu, görevini her zaman adaletle yaptığını ve ahalinin sadece kendisinden hoşnut olmakla kalmayıp, onu mütesellim olarak görmek istediğini anlatır. Savaş zamanında da Anadolu Valisi'ne erzak ve para toplaması için tüm yardımı yapmıştır. Hakkında kötü söylenen her ne var ise, yalandır, iftirâdır! ${ }^{85}$ Ancak bu çabalar fayda etmez ve tam tersine, Nasuh Ağa'nın kesik başını Anadolu Valisi'ne götüren çukadara ve maiyetindeki iki Tatara yaklaşık 2.500 kuruşluk hediyeler verilir. Daha da önemlisi aynı sona uğramamak için Nasuhzâdelerin bir kısmı kaçarlar. Nasuhzâdelerin ve kapı halkından adamlarının muhallefatlarının ayrıntılı bir defteri olmamakla beraber, konuyla görevli mübaşirin değerlendirmesi sonucunda "avane ve müteallikatının" serveti 190.000 guruşa yaklaşır. ${ }^{86}$

Nasuh Ağa’nın izalesinden önce bile yakın aile efradı merkezî idarenin takibi altındaydı—Nasuh Ağa’yı yakalamak ve cezalandırmakla görevli olanlar bu takibi de sürdürmekteydi. ${ }^{87}$ Yine de Nasuh Ağa'nın cezası infâz edildikten ve muhallefat defteri çıkarıldıktan sonra bir pazarlık dönemi başlar. Bunun ne tür bir pazarlık olduğu, nasıl sürdürüldüğü açı değil ama merkezî idare bu durumda da müsadere konusunda fikrini değiştirmişe benzer; 1819 tarihli Kütahya

83 BOA, Cevdet Adliye 1814.

84 BOA, Cevdet Adliye 2169.

85 BOA, Hatt-1 Hümâyûn (HH) 47913-C1.

86 BOA, Cevdet Maliye 6519, “Maktul Nasuhoğlu’nun 'avane ve müteallikattan kendüyle

firar eden ma'lumu’l-esâmî mezbûrların işbu deftere kayd ve tahrîr olunduğu üzere kaffe-yi muhallefatları inzimâm-1 rey' ve mübaşir kulları ma'rifeti ve ma’rifet-i şer'le bâ-taharrî ve'likdâm tahrîr ve esâmileri müfredatı tahtına bahaları vaz’ ve tahrîr olunub yekün-1 mezbûre üzere 187.949,5 guruşa resîde olduğu işbu mahalle kayd olundu”.

87 BOA, Hatt-1 Hümâyûn (HH) 47913 C ve D2. 
sicilinde en az beş farklı belgede aile efradının müsadere edilecek servetlerinin bağışlandığı ve geri verildiği belirtilir. ${ }^{88}$ Sonuç olarak yaklaşık 190.000 guruşun 100.000 kuruşa yakını Nasuhzâdelere bağışlanır. Dolayısıyla, Nasuhzâdeler servetlerinin bir kısmını korumuş olsalar da bölgedeki siyasî güçlerini yeniden kuramazlar.

Abbas Ağa gibi Nasuhzâdelerin de ortadan kalkması Germiyanzâdelerin önünün tamamen açıldığı anlamına gelmiyordu. 1802'de yeni vali Seyyid Ömer Paşa, Germiyanzâde El-Hac Ali’nin mütesellimliğini onaylamış olsa da bu uzun sürmedi.$^{89}$ Kısa bir süre sonra Germiyanzâde Ali önce görevden alınd $1,{ }^{90}$ ardından da katledildi. ${ }^{91}$ Bu gelişmelerden önce Germiyanzâde ailesinde bir kayıp daha yaşanmıştı; Germiyanzâde El-Hac Mustafa 1801'de vefat etmişti. Germiyanzâde Mustafa merkezî idare tarafından ortadan kaldırılmamıştı ama ölümünden hemen sonra Zağnos Paşazâde Ahmed servetinin müsaderesi için görevlendirilmişti. ${ }^{92}$ Bunun üzerine ayrıntılı bir muhallefat defteri hazırlandı ve Divân-1 Hümâyûna gönderildi. ${ }^{93}$ Deftere göre Germiyanzâde Mustafa'nın serveti 63,342 kuruştu ki bu dönemin Kütahyası için önemli bir miktardır. Ancak daha yakından bakıldığında bu miktar ilk bakıştaki kadar yüksek değildir çünkü Mustafa’nın farklı kişilere 42.000 kuruş borcu vardır. Her şeyden önce babası Hacı Memiş Ağa'nın vefatından sonra kızkardeşlerinin hisselerine bedel ödemeden el koyduğu için muhallefatındaki en önemli borç kalemlerinden biri 12.000 kuruşluk borcuydu. Diğer borçlarının da toplamı 30.000 kuruşa varıyordu. Defin işlemleri için gerekli olan harcamalar da eklenince Hacı Mustafa'nın serveti aslında 19.145 kuruş ediyordu—ki bu da bir ayan ailesi için oldukça mütevazı bir miktardı.

İlgili muhallefat defterinden, Hacı Mustafa’nın esas olarak kırsal bölgede yatırım yapan küçük ayanlardan olduğu anlaşılıyor. Hatırı sayılır miktarda ev eşyası ve bazı mücevheratı olmasına rağmen-dönemin koşulları el verdiği ölçüde— lüks içinde yaşayan biri değildi. Yatırımları da şehirdeki zanaat erbabı ile olmaktan

88 Rabia Canpolat (Dağ), "11 Numaralı Kütahya Şeri’iyye Sicili (1819-1820m / 1234-1236)” (Yayınlanmamış Yüksek Lisans Tezi), Fırat Üniversitesi Sosyal Bilimler Enstitüsü, 2003. (K11/60-61-62-63-64-65).

89 Karacagil, “6 Numaralı Kütahya Şer’iye Sicili Transkripsiyonu ve Edisyon Kritiği”, (K6/16). 90 Karacagil, "6 Numaralı Kütahya Şer’iye Sicili Transkripsiyonu ve Edisyon Kritiği”, (K6/31). 91 Karacagil, "6 Numaralı Kütahya Şer’iye Sicili Transkripsiyonu ve Edisyon Kritiği,” (K6/34,50), BOA, Hatt-1 Hümâyûn (HH) 4214; Cevdet Adliye 510.

92 BOA, Cevdet Maliye 2244.

93 BOA, Cevdet Maliye 1563.5. 
çok kırsal alana yaydığı kredi ilişkileri vasıtasıyla genişlemişti. ${ }^{94}$ Kütahya’da (Lala Paşa mahallesindeki) 350 kuruş eden bir "çanakçı kârhanesi" ile kıyaslandığında üç çiftliği (7.500 kuruşluk), hayvanları ve 14-15 köye verdiği 15.000 kuruşluk borçlar yatırımlarını nereye yaptığı açıkça gösterir.

Bu hesaplardan sonra—aynen Nasuhzâdeler örneğinde olduğu gibi—bir pazarlık süreci de başlamıştı. Hazırlanan bir raporda muhallefat defterinin yanı sıra Hacı Mustafa’nın ailesinin zaten zannedildiği kadar iyi durumda olmadığı, bölgedeki çekirge istilâsı yüzünden çiftliklerinin daha da zor durumda kalacağı için 19.145 kuruşun kendilerine bırakılması önerilir. Yine benzer durumlarda olduğu gibi belli bir miktar (bu durumda 10.000 kuruş) iki taksit olarak bir yılda, geri kalanı da zaman içinde ödenecektir.

Germiyanzâde Hacı Mustafa'dan sonra sıranın Germiyanzâde Hacı Ali'nin servetine geleceği aşikâr gibiydi. ${ }^{95}$ Diğer pek çok ayan gibi Ali de ahaliye zulm etmekle suçlanıyordu. Anadolu Valisi Ömer Paşa’nın 1802'de gönderdiği bir mektupta "Medine-i Kütahya'da ta’ayyün ve teferrüd eden Germiyanoğlu Hacı Ali'nin fukaraya eylediği mezâlim ü tảaddi ve rencide vü tecâvüzü sebebiyle medine-yi merkûmenin etraf ve civarında olan nevâhilerin sükkanı terk-i evtân [ettikleri] ve ekseri perâkende ve perişân” oldukları belirtiyordu. ${ }^{96} \mathrm{Bu}$ tür ifadeler aslında ayanlarla-ahali arasındaki ilişkiyi betimlemek ve merkezî idarenin doğrudan müdahalesini meşrû kılmak için neredeyse kelimesi kelimesine benzer belgelerde bulunabileceği için durumun tam olarak ne olduğunu kestirmek imkânsız. ${ }^{97}$ Ancak ilgili yazıda çok daha somut bir suçlama da vardır: Hacı Ali eyâlet masrafını toplarken masrafları fazla gösterip toplanan yaklaşık 65.000 kuruşun yarısını cebe indirmiştir. Bu yüzden cezası da (kesik başının İstanbul'a gönderilmesi) diğerlerine bir ibret olmalıdır. ${ }^{98}$

94 Meselâ ahkâm defterlerinde Germiyanzâdeler üzerine rastlanan ender hükümlerden birinde, Hacı Mustafa’nın 1790'ların sonuna doğru Örencik nahiyesindeki bazı karyelerdeki çeşitli kişilere 4.477 kuruş borç verdiğini ancak alacaklarını tahsil edemediğini ve bu adaletsizliğin düzeltilmesini istediğini okuruz. BOA, Anadolu Ahkâm, 125/231.

95 Karacagil, “6 Numaralı Kütahya Şer’iye Sicili Transkripsiyonu ve Edisyon Kritiği” (K6/34) 96 BOA, Hatt-1 Hümâyûn (HH) 4214.

97 Meselâ, "teferrüdden" kastedilenin ne olduğu daha çok somut olarak tanımlayabilmek için kavramı gerek sosyal gerekse de hukuk tarihi açısından daha fazla çalışmak gerekmektedir. Ayrıca, belgelerin dilinden çoğu zaman ahaliden kaç kişinin toprağını, hangi koşullarda bıraktığı belirmek çoğu zaman çok zor.

98 Hatt-1 Hümâyûn (HH) 4214, Karacagil, “6 Numaralı Kütahya Şer’iye Sicili Transkripsiyonu ve Edisyon Kritiği” (K6/31). 
Germiyanzâde Hacı Ali'nin kayıtlara yansıyan toplam serveti 50.000 kuruş kadardı. Borçları ve defin masrafları da düşülünce merkezî idarenin müsadere edeceği miktar 40.000 kuruşa iniyordu. ${ }^{99}$ Hacı Ali'nin muhallefat defterinden çıkan ayan profili ise Germiyanzâde Hacı Mustafa'ya oldukça benzerlik gösterir. Yine servetini esas olarak kırsal alanda biriktirmiş ve değerlendirmiş, rahat yaşayan ama lüks tüketim içinde olmayan bir Anadolu ayanı. Pek çok eşya ve giysinin yanında, Hacı Mustafa'dan bir derece daha fazla lüks sayılabilecek eşyaya sahipti; İngiltere'de yapılmış bir dürbün, bir saat ve bazı mücevherat gibi. Ama gerçek serveti kırsal alandan geliyordu; ambarlarda depolanmış tahılları, hayvanları ve değirmenleri vardı. Hacı Ali herhangi bir dükkâna sahip değildi ve anlaşılan o ki herhangi bir ortaklığı da yoktu. Belirli bir borç-alacak ağı kurmuştu ama bu gayet sınırlıydı; en yüksek miktar Şuhud ahalisinden alacağı olan 1,100 kuruştu. Kendisinin toplam borcu ise 9,500 kuruştu. Kısacası, Hacı Ali elinde büyük bir servet biriktirmiş, çevresinde alacak ilişkilerine dayalı geniş bir ağ kurmuş, ya da servetini kırsal alan ve şehir arasında bölüştürmüş, bölge dışı pazarlara ticaret yapan biri değildi. Dolayısıyla aslında merkezî idare açısından idarî özerklik isteyecek ya da bir ayaklanma çıkaracak kadar güçlü bir ayan değildi. Sonunda Hacı Ali’nin serveti mirasçılarına 7.500 kuruş bedel karşılığında bırakılmıştı. ${ }^{100}$

Merkezi îdare Germiyanzâdelere Hacı Ali'nin servetini bırakırken "vereseyi merkûme pâye-yi merhamet oldukları zahir olmağla 7.500 kuruş bedel verilmek üzere muhallefat-1 merkûmenin verese-yi müteveffâya terki” demiş olsa da, herhalde bu karar sadece merhamet hissine indirgenmeyecek siyasi ve ekonomik denge hesaplarının bir sonucuydu. Daha açlk söylemek gerekirse, merkezî idarenin nakit para sıkıntısı çektiği bir dönemde muhallefatın bedel karşılığı nakte çevrilmesi vakit alabilecek hukukî ve idarî işlemleri hızlandırmak ve daha kısa sürede nakit bulmak gibi pratik bir işleve sahipti. Ayrıca, sosyoekonomik dayanaklarını tamamen ortadan kaldırmadan, Germiyanzâdeleri diğer ayanlara karşı kullanmak da bu hesapların bir parçasıydı. Meselâ, iki sene sonra (Germiyanzâde Hacı Mustafánın oğlu ${ }^{101}$ ) Germiyanzâde Mehmet mütesellim olarak tayin edildiğinde görevlerinden biri bölgede Eskişehirli Kumarcı Abdullah ve Memiş

$99 \mathrm{Bu}$ değerlerin yaklaşık olmasının nedeni iki farklı belgede iki birbirine yakın ama yine de farklı miktarın kayıt edilmiş olması. Bk. BOA, Cevdet Maliye 22279'de 49,621 kuruş, altı numaralı Kütahya Sicilinde ise 53,156 kuruş, Karacagil, "6 Numaralı Kütahya Şer’'iye Sicili Transkripsiyonu ve Edisyon Kritiği," (K6/50).

100 BOA, Cevdet Maliye 22279.

101Öznur Kutluğ Bozkurt, "Kütahya Şer'iye Sicilleri 8 Numaralı Defterinin Transkripsiyonu ve Değerlendirilmesi," (Yüksek Lisans Tezi Dumlupınar Üniversitesi, 2006), (K8/42). 
kardeşlerin bir süredir devam eden şekavetinin önünün alınmasıyd $1^{102}$--ki benzer emirler 1799'da Nasuh Ağa’ya da gönderilmişti. ${ }^{103} \mathrm{Bu}$ görev başarıya ulaşmamış olmalı ki 1813 ve 1815 arasında merkezî idare hâlâ Kumarcı kardeşleri hem siyasî-askerî hem de ekonomik olarak kontrol etmeye çalışıyordu: Kumarcıların bölgedeki mukataaları malikâne olarak ellerine geçirmelerini engelleyerek, ${ }^{104}$ ya da kendilerini ve adamlarını ortadan kaldırmaya çalışarak. Bu tedbirleri almak ve uygulamak gerek ayanların kendi aralarında sürekli değişen güç ilişkileri gerekse merkezî idarenin coğrafî olarak payitahta yakın bölgeleri bile yeteri kadar denetlememesi yüzünden kadar kolay değildi. Gönderilen bir rapor 1813'de Kütahya mütesellimi olan Kalyoncu Ali'nin Kumarcı'ya arka çıkacağının neredeyse kesin olduğunu, Kumarcı'nın peşine daha önce düşüldügünü ama başarısız olunduğunu, Eskişehir-Kütahya civarındaki diğer eşraf görevlendirilse bile, başarı şansının belirsiz olduğunu anlatır. ${ }^{105}$ İki sene sonra bir başka maliye belgesinden Kumarcı Abdullah'ın ortadan kaldırıldığı anlaşılır çünkü bölgedeki mukataalardan kalan borcunun tahsil edilmesi gerekmektedir. ${ }^{106}$

Bu kadar hızlı değişen sosyo-ekonomik koşullarda Germiyanzâde Mehmet' in mütesellimliğinin uzun sürmemesine şaşmalı. Bununla birlikte 1809 'da bir başka Germiyanzâde, bu kez Süleyman Ağa mütesellim olur, ${ }^{107} 1810$ 'un ilk yarısına kadar görevde kalır. ${ }^{108}$ Azledildikten ${ }^{109}$ sonra 1811 'de yeniden tayin edilir. ${ }^{110} \mathrm{Bu}$ yıllarda hem Germiyanzâde Mehmet hem de Süleyman merkez tarafindan zahire ve asker toplamakla görevlendirilir. Germiyanzâdelerin mütesellim olarak anıldıkları en son emirlerden birinde kendilerinden 300 süvari ve 1000 piyade nefer toplamaları isteniyordu. ${ }^{111}$ Ancak bunun hemen ardından Germiyanzâdelerin

102 BOA, Cevdet Dahiliye 2847.

103 BOA, Cevdet Zaptiye 945.

104 BOA, Cevdet Maliye 4286. Kumarcı için şunlar yazılıdır, "huzûr-1 hümayûn-1 şahaneye 'arz olunan takririmizde ifâde ve beyân olundukda ba'zı olmayacak adama mukataa verilmesi na-münasib olmağla defterdara tenbih idesin ol makulelere mâlikâne verilmesün deyü hatt-1 hümayûn-1 şahane [sudur olmağla].”

105 BOA, Hatt-1 Hümâyûn (HH) 52778.

106 BOA, Cevdet Maliye 5603.

107 BOA, Cevdet Dahiliye 2370.

108 Bozkurt, "Kütahya Şer'iye Sicilleri 8 Numaralı Defterinin Transkripsiyonu ve Değerlendirilmesi”. (K8/14, 15, 18, 19).

109 Bozkurt, "Kütahya Şer'iye Sicilleri 8 Numaralı Defterinin Transkripsiyonu ve Değerlendirilmesi," (K8/63).

110BOA, Hatt-1 Hümâyûn (HH) 30996; 31145.

111 Bozkurt, "Kütahya Şer’iye Sicilleri 8 Numaralı Defterinin Transkripsiyonu ve Değerlendirilmesi” (K8/42). 
bölge ayanı olarak tanınmaları ve mütesellimlikleri neredeyse ani bir şekilde sona erer-en azından şer'iyye sicillerine yansıdığı haliyle. 1820'lerde Germiyanzâde Mehmet Ağa hâlâ "vücûh-1 hanedan"dan sayılmaktadır ${ }^{112}$ ve Germiyanzâdeler tevzi defterlerinin şahitleri arasında yer almaya devam ederler. ${ }^{113}$ Yine de 1790 1810 arasındaki göreli olarak artan güçlerine erişemezler. Tipkı kuruluş yıllarında Osmanlı beyliğinin başatlığını kabul ettirdiği yıllarda olduğu gibi 19. yüzyıl başında da merkezî idare yeniden ama farklı bir siyasi düzen içinde kurulurken Germiyanzâdeler bu dönemi yok olmadan atlatmayı başarırlar. Hiç şüphesiz siyasî, iktisadî ve kültürel sermayeleri yine Tanzimat sistemi içerisinde yükselmelerine izin verecektir ama artık—seyrekleşen bir şekilde—şer'iyye sicillerinde yer aldıklarında sadece sıradan bir Kütahya sakini olarak zikredileceklerdir. ${ }^{114}$

\section{Sonuç Yerine}

Ayanlar siyasetinin çok boyutlu, çok hızlı değişen dinamikleri ayanları tek ve kendi içinde tutarlı ekonomik, siyasal, askerî veya idarî hedefleri olan bir grup ya da sınıf olarak tanımlamaya da izin vermez. Dolayısıyla Albert Hourani'nin 1968'de öncü çalışmasında belirttiği yerel ile merkezî idare arasındaki arabuluculuk vasfı ayanlık vasıflarından sadece biridir ${ }^{115}$ ve zaman içinde değişir. Ayanlar büyük oranda bölgesel koşulların belirlediği bir zemin üzerinde kendi hareket alanlarını belirlerler. Merkezî idarenin de hangi ödünleri, nerede ve nereye kadar vereceği, ayanları hangi noktaya kadar yerel bir arabulucu ya da temsilci olarak göreceği ve kullanacağı yine aynı koşullar içinde şekillenir. Hepsinden önemlisi özellikle Arap eyaletleri üzerine yapılan çalışmaların bazıları-Mısır, Yemen ve Kuzey Afrika dışında, Suriye, Irak, ve kısmen Filistin'de—adem-i merkezileşmenin ve ayanların giderek daha önemli bir rol oynamasının bağımsızlık için verilen bir mücadele olmadığını, yerel güç odaklarının kendi aralarında mücadele ederken bile Osmanlı devletinin meşruiyetini doğrudan sorgulamadıklarını gösteriyor. Belki de tam tersine, merkezî idare bu eyaletlerde 18. yüzyıldan 19 .

112 Hüseyin Erol, “13 Numaralı Kütahya Şer'iyye Sicili Transkribe ve Değerlendirmesi” (Yüksek Lisans Tezi, Kırıkkale Üniversitesi, 1997), (K13/3).

113 Hüseyin Erol, "13 Numaralı Kütahya Şer’iyye Sicili Transkribe ve Değerlendirmesi," (K13/70, 109).

114Mustafa Yavuz, "Kütahya Şer'iye Sicilleri 15 Numaralı Defterinin Transkripsiyonu ve Değerlendirilmesi” (Yüksek Lisans Tezi, Sosyal Bilimler Enstitüsü, 2009, (K15/7, 16).

115 Meselâ Beshara Doumani, yerel ayanlar kadar, hatta daha fazla Nablus ve çevresinde arabuluculuk için bile tüccarların rolünü vurgular. Beshara Doumani, Rediscovering Palestine: Merchants and Peasants in Jabal Nablus, 1700-1900 (Berkeley: University of California Press, 1995). 
yüzyıla geçerken daha derinlemesine nüfûz etmektedir. ${ }^{16}$ Hatta Mısır gibi göreli özerkliğini korumuş bölgelerde bile güçlü haneler ve kapıhalkları oluşurken, bunlar büyük ölçüde Osmanlı hanedanlığının ve merkezî idarenin yarattığı modele benzer bir şekilde oluşurlar. ${ }^{117}$

18. yüzyılın sonlarından itibaren ayan siyasetinin aldığı farklı biçimler gibi merkezî idare de pek çok farklı biçimde iktidarını yeniden tahsis etmeye çalışıyordu. Malî kontrol, yeni bir ordunun kurulması, gerektiğinde ayanların şiddet kullanılarak ortadan kaldırılmasının yanında devletin görünürlügünün artması da bu yeni merkezîleşme çabasının bir parçasıydı. Daha somut olarak söylemek gerekirse, meselâ Kütahya sarayının—yani dönemin hükümet konağının—onarımı bu çabanın önemli bir parçasıydı. ${ }^{118}$ Daha önce yanmış ve kullanımı kısıtlanmış Kütahya sarayının yeniden inşasına 1790 'ların ilk yıllarında karar verilmiş olmalı. 1795 'de sarayın onarımı ve ek bazı binaların inşası için gerekli meblağ 110.000 kuruştan fazlaydı. Malî bir darboğaz varken, bu miktarı kısa sürede toplamak neredeyse imkânsızdı. Ayrıca, bu girişim tek bir kişinin taahhüt edebileceğinden daha büyüktü. Böyle olduğu için de Kütahya sancağından daha geniş bir alana dağıtılması gerekiyordu. Bunun sonucunda 21.090 kuruşun Kütahya sancağından, 18,989 kuruşun Hüdavendigârdan ve geri kalan 72.000 kuruşun da Anadolu eyaletinin geri kalanından toplanmasına karar verilmiş, ${ }^{119}$ tahsilat için de ilk önce Karaosmanzâdelerden El-Hac Ömer düşünülmüştü. ${ }^{20}$ Karaosmanzâde'nin tahsilata başlayıp başlamadığı açık değil ancak bir yıl önce bile Ankara ahalisi kendi üzerlerine düssen payı (6.666 kuruş) ödeyemediklerini ve kıtlıkla beraber gelen bu ek yükün kendilerini daha güç duruma soktuğunu belirtmişlerdi. Bunun üzerine Kütahya sarayının tamir ve inşası için gerekli olan masrafları yeniden değerlendirmek için yeni bir mimar tayin edilmiş, bunun sonucunda da masraflar yekûnu 80.000 kuruşa kadar düşmüştü. ${ }^{121}$ Ancak bu hâlâ yüklü bir miktardı.

116Bu çalışmaların toplu bir değerlendirmesi için bkz. Khoury, "The Ottoman Centre”.

117 Hathaway, The Politics of Households in Ottoman Egypt, ve "The Household: An Alternative Framework".

118BOA, Cevdet Dahiliye 1365.

119 Masraflar tam olarak 113.031 kuruş olarak hesaplanmıştı; BOA, Cevdet Dahiliye 8875. Burada bu belge ilgili bir sorundan bahsetmek gerekli; hazırlanan taksimat defterine ait iki belgedeki tarihler 1211 ve 1201 olarak yazılmış. Anadolu Eyaletinin sancakları için hazırlanan taksimat defterinde öncelikle Saruhan'dan Sultanönü’ne genel bir taksimat yapılmış ve Kütahya ile Hüdavendigar sancaklarının kazaları için daha ayrıntılı bir taksimat hazırlanmış. Bu belgenin tarihi ise 1201 olarak yazılmış. Görüleceği gibi konuyla ilgili diğer tüm belgelerin 1209 - 1211 arasında olduğu göz önüne alınırsa, bir kâtip hatası olduğunu düşünmek ve kâtibin tarihi atarken birden sonra on yazmayı unutmuş olduğunu düşünmek çok yanıltıcı olmaz.

120 BOA, Cevdet Adliye 8074.

121 Yazılan arzuhal üzerine yine BOA, Cevdet Adliye 8074. 
Öyle anlaşıllyor ki tahsilatta çıkan güçlüklere rağmen tamir ve inşaatın bir kısmı 1796'da tamamlanmış olsa da bina tamam değildi. Bunun üzerine ikinci bir "keşif defteri" gerekli olmuştu. Tayin olunan mimardan bu ikinci defterde hem bitirilen yerlerin bir listesi hem de yeni tamirat ve inşaat kalemlerinin neler olduğunu bildirmesi isteniyordu. Defterlere göre 55.000 kuruş civarında bir meblağ harcanmışt1 ${ }^{122}$ ve eksikliklerin giderilmesi için 22.000 kuruş daha harcanmalıydı. ${ }^{123}$ Bu miktar aslında hesap edilen 80.000 kuruş civarında ama tamirat ve yeni binalar için ne kadar toplandığı açık değil. Yine de yüklü miktar gerektiren bu inşaat faaliyetinde işler yolunda gitmemiş gibi gözüküyor. Belgelerde açık olarak ifade edilmese de daha önceki belgelerde adı geçen Kütahya sarayı bina emini Salih Ağa’nın tam da bu sıralarda ortadan kaybolması İstanbul'da sorgulanmak üzere Malkara ve Keşan taraflarında aranıyor olması ortada bir yolsuzluk ya da kötü ifâ edilmiş bir görev olduğunu da düşündürüyor. ${ }^{124}$

Tamir ve inşaatla ilgili belgeler kullanılacak malzemenin nitelik ve niceliklerinden, yeni inşa edilmesi gereken bina ve odaların boyutuna kadar ayrıntılı bilgiler içeriyor. Mimarlık tarihi için de aydınlatıcı olabilecek bu bilgileri bir kenara bırakırsak, anlaşıldığı kadarıyla yeni bina—ya da binalar bütünü—eskisinden daha fazla kişiyi barındırmak üzere tasarlanmıştı. Görevliler için farklı bölümler, misafir odaları, yeni ve daha büyük bir kiler ve top yerleştirmek için yeni sundurma alanları düşünülüyordu. Bunlar büyük konakların daha önce de işlevleri arasındaydı şüphesiz, yine de Kütahya sarayının adının tedricen hükümet konağı olarak anılmaya başlaması da bir tesadüf olmamalı. 1793 ile 1797 arasındaki göreli sakinlik ve barış döneminde merkezî idare iktidarını sadece ayanlar aracılı̆̆ 1 ile değil, aynı zamanda daha bürokratik olarak da kurmaya çalışıyordu. Hemen her yönüyle idarî merkezileşme Tanzimat'ta gerçekleşecek olsa da yeni Kütahya sarayının hükümet konağına evrilmesi sembolik bir geçişten fazlasını ifade ediyordu.

Kütahya sarayı gibi, 19. yüzyılın hemen başında Kütahya kalesinin işlevi de bölgedeki güç dengesi hakkında fikir verir. Kale ne valinin konağı olarak kullanılıyordu ne de şehrin ve bölgenin idarî merkezi idi, ama hem hapishane hem de cephanelik olarak işlev görüyordu. ${ }^{125}$ Kalenin merkezi konumu ve işlevi kale kethüdasının—dolayısıyla merkezî idarenin—gücünü korumasına izin vermişti.

122 BOA, Cevdet Adliye 8891.

123 BOA, Cevdet Adliye 8357.

124 BOA, Cevdet Adliye 9335.

125 Karacagil, “6 Numaralı Kütahya Şer’iye Sicili Transkripsiyonu ve Edisyon Kritiği” bu konug da pek çok belge içerir, (K6/38-50). 
Çevre ayanlara karşı girişilen askerî harekatlarda da kaledeki mühimmatın ayanlara ancak zimmetlenerek verilmesi, en azından Kütahya ve çevresi söz konusu olduğunda, ayanların siyasi ve askeri gücünün sınırlarını gösterir.

Böyle bakıldığında büyük ayanlarla diğerlerini ayıran en önemli özelliklerden biri tam da idarî basamakları ne kadar çıktıkları ve siyasal yapı içinde ne kadar ilerledikleridir. Balkanlarda, Anadolu'da ve Arap topraklarında Ahmet Cezar Paşa, Mehmet Ali Paşa, Tepedelenli Ali Paşa, Pasvandoğlu Osman Paşa, ya da Karaosmanzâdeler gibi ayanlar ve hanedanlıklar için en önemli adımlardan birinin-her zaman ele geçirememiş olsalar da—eyâlet valiliği olması boşuna değildir. Bunlar da çoğunlukla mütesellimlik aşamasından geçmişler, ama yükselerek merkezî idarenin daha önemli bir parçası olmuşlardı. İşte bu ayan grubu merkezî idarenin bir yandan gerçek rakipleri ve diğer yandan ise ortaklarıydılar. $\mathrm{Bu}$ anlamda da Germiyanzâdeleri ayanlardan saymak mümkün ise de yönetici seçkinlere dahil etmek zordur. Zaten gittikçe bürokratikleşen merkezî idarenin ve sultanın bu iki grubu algılayışı ve onlara yaklaşımı da farkı ortaya koyar. ${ }^{126}$ Eğer 1808'deki Sened-i İttifak ayanların siyasî gücünün merkezi idare tarafından tanındığı yeni bir güç dengesinin kabulü olarak olarak görülecekse, hatırlamak gerekir ki, bu yeni dengenin ilk kurbanları Germiyanzâde gibi görece güçsüz olan ayanlard.

Bu güç dengesi içinde belirleyici olan sadece merkezî idare değildi; ayanların da farklı tepkileri vardı. Kimisi 1790 'larda, kimisi daha önce başlayan merkezîleşme uygulamaları nasıl farklı ritmler izlemişse, verilen tepkiler de öyle oldu. Her ne kadar Avrupa ve Rusya'yla olan askerî rekabet ve büyük ölçüde bunun sonucu olan malî merkezileşmeyi birbirinden ayırmak güç olsa da ayanlar açısından bu iki merkezîleşme sürecinin farklı etkileri olacaktır. Bitmek bilmeyen ama gittikçe daha da zorlaşan ve pahalıya mal olan savaşlara zahireden askere kadar gerekli lojistik desteği bulmak için merkezî idarenin büyük-küçük ayanların arabuluculuğuna ihtiyacı vardı. Ayanların ise bu tür desteği vermekte çoğu zaman bir çekincesi yoktu. Ancak idarî ve özellikle malî merkezileşme siyasî ve ekonomik ayrıcalıkları hedef aldığı oranda ayanların da özerkliğini tehdit ediyordu. Dolayısıyla hem ayanlar hem de merkezî idare açısından gerilimli olan bu süreçte farklı stratejilerin geliştirilmesi, ayanların kendi aralarında ve İstanbul ile farklı ittifaklar kurmaları ve bunların her zaman kolaylıkla öngörülmeyen sonuçlarının

126 Bu farklılıklar için, Ali Yaycıŏlu, "Provincial Power-Holders and the Empire in the Late Ottoman World: Conflict or Partnership?,” The Ottoman World, C. Woodhead (ed.), (London,: Routledge Press, 2011), s. 436-465. Meselâ Sultan II. Mahmud'a kimlerden borç alması gerektiği konusunda verilen raporlarda büyük ayan grubuyla diğerleri arasındaki fark açıkça belirtilmiştir. 
ortaya çıkması kaçınılmazdı. Özellikle 1806 - 1809 dönemi farklı ittifak gruplarının iktidar mücadelesinin doruğa çıktığı dönemdir. ${ }^{127} 1826$ 'da ortadan kaldırılana kadar, yeniçerilerin ağırlıklarını sürdürdüğü yıllar boyunca ayanlar da değişik ittifakların parçası olarak farklı yollar izleyeceklerdir.

Nizam-1 Cedid ile birlikte ordunun merkezîleşmesi sadece İstanbul değil, taşra için de belirleyici idi. 1826'da Kütahya’nın diğer dört vilayet ile (Erzurum, Çankırı, Bolu ve İzmir) taşra alaylarının kurulacağı yerler arasında olması bu açıdan önemlidir. ${ }^{128}$ Böyle bakıldığında ise III. Selim dönemi, Kütahya ve çevresindeki güç dengesini gözeterek merkezî idarenin iktidarını tedrici ve tutarlı bir politika izleyerek kurduğu bir dönem olarak görülebilir.

18. yüzyılın son dönemi içinde değerlendirildiğinde Germiyanzâdelerin bölgenin uzun dönemli dinamiklerine paralel bir biçimde fazla zenginleşemedikleri, meselâ İzmir'in gittikçe artan önemi sayesinde Batı Anadolu'da oluşan yeni ticari ağların parçası olmadıkları, bu yüzden de Karaosmanzâdelere kıyasla çok daha güçsüz kaldıkları anlaşııır. Daha yakındaki Bursa ile bile çok sıkı ticarî ilişkiler ya da kredi bağları içinde olduğu söylenemez. Gerek bölgeler ötesi ticaret ağları gerekse askerî sefer güzergâhının doğrudan üzerinde olmayan Kütahya sanki Evliyâ Çelebi'nin 1671'deki ziyaretinden ve izlenimlerinden beri 19. yüzyıl başına kadar çok fazla değişmemiştir. Germiyanzâdelerin daha güçlü siyasi rakipleri ve daha zengin bölgeler arasındaki sıkışmışlığının yanında tahıl ve hayvancılık ağırlıklı üretimi de 18. ve 19. yüzyılın tütün, pamuk ya da şeker gibi gittikçe daha çok talep gören ürün ağlarının dışında kalmasına yol açmış, tahıl üretimi de daha ziyade ordunun iaşesi ile sınırlı kalmıştır. Dolayısıyla Germiyanzâdeler gibi ayanlar kırsal alana ve üretime yatırım yapsalar da bunun önemli miktarda sermaye biriktirmelerine yardımcı olduğunu söylenemez. Zanaat üretimi ile olan ilişkileri de—an azından muhallefat defterlerinden anlaşıldığı kadarıyla—çok sınırlı olduğu için bu sektöre yatırım yaparak sermaye biriktirme yoluna gittikleri de söylenemez. ${ }^{129}$

Kütahya'nın bu ağların bir parçası olması için 19. yüzyıl sonunu, hatta 20. yüzyıl başlarını beklemek gerekir. 19. yüzyılın ikinci yarısında önce İzmir’i

127 Görece yeni tarihli bazı çalışmalar için, Aysel Yıldız, "Vaka-yı Selimiyye or the Selimiyye Incident, a Study of the May 1807 Rebellion”, (Ph.D., Sabancı University, 2008). Yaycioğlu, "The Provincial Challenge”. Kadir Üstün, "The New Order and Its Enemies: Opposition to Military Reform in the Ottoman Empire, 1789-1807” (Ph.D., Columbia University, 2013). 128 Aksan, Ottoman Wars 1700-1870 an Empire Besieged. s. 329.

129 Bugün Kütahya için çok önemli olan çinicilik, 17. yüzyıldan itibaren İznik'le rekabet etmesine rağmen, İznik’ in daha ziyade yüksek kaliteli lüks üretimi zayıflayıp, neredeyse tamamen durunca da pazarı tek başına ele geçirmez. 


\section{MURAT DAĞLI}

hemen arka-bölgesine ve dolayısıyla bu bölgeyi de küresel ticaret ilişkilerine bağlayan demiryolları yapılacak, zaman içinde bu ağ geliştikçe Kütahya da buna dahil olacaktır.

\footnotetext{
The Politics of the Local Notables at the end of the 18th Century and the Germiyanzades

Öz Ayanlar Osmanlı tarihinin en çok ve belki de en iyi çalışılmış alanlarından biri olmaya adaydır. Hem somut tarihi hem de daha kuramsal yaklaşımlar bu çalışma alanını genişletse de, araştırmalar genellikle söz konusu olanlar 18. yüzyılın güçlü ayanları, dolayısıyla görece güçsüz ayanlar hakkında bilgimiz sınırlıdır. Bu yazı ayanlarla ilgili bilgi birikime bir katkı yapmayı amaçlar. Yazının esas amacı Kütahya ayanlarından Germiyanzâdeler'in 18. yüzyılın sonunda ve 19. yüzyılın başındaki durumları hakkındaki bilgimizi ilerletmek ve bölgedeki diğer ayanlar arasındaki rekabet, merkez-çevre ilişkilerinin dinamiği ve 18. yüzyıl sonundaki mali ve idari politikaların ekonomik ve sosyal dönüşüme etkileri gibi daha genel tartışmalar için bazı tespitlerde de bulunmaktır.

Anahtar kelimeler: Germiyanzâdeler, Kütahya, ayanlık siyaseti, 18. yüzyıl, merkezileşme.
}

\section{Kaynakça}

\section{Arşiv kaynakları}

\section{Şer'iyye Sicilleri}

Kütahya Şer'iyye Sicilleri, 3, 4, 5.

\section{Başbakanlık Osmanlı Arşivi, BOA}

Anadolu Ahkâm, 35/952, 48/592, 55/43-388-513, 85/188-484, 87/99, 89/650, 91/825, $125 / 231,127 / 459$.

Baş Muhasebe-Muhallefat (D. BŞM. MHF), 12701, 12856, 12993.

Cevdet Adliye, 1523, 1814, 2169, 2407, 3637, 3650, 8074, 8357, 8891, 9335.

Cevdet Dahiliye, 57, 1365, 2370, 2847, 5160, 7340, 8875, 9899, 9995.

Cevdet Evkâf, 2380.

Cevdet Maliye, 1198, 2034, 2051, 2244, 2271, 3418, 4286, 4371, 4964, 5052, 5603, 6519, 6910, 6941, 7359, 11880, 13741, 15635, 18095, 21900, 22279, 23728, 26880, 27165.

Cevdet Zaptiye, 945, 586, 2477, 3094, 3519.

Hatt-1 Hümayun (HH), 1973, 4214, 6471, 9453, 9705, 9724, 9752, 9836, 10114, 10292, 11233, 11555, 11625, 14802, 16102, 30996, 31145, 52778, 55212. 


\section{İkincil kaynaklar}

Aksan, Virginia: "The One-Eyed Fighting the Blind: Mobilization, Supply and Command in the Russo-Turkish War of 1768-1808", Ottomans and Europeans: Contacts and Conflicts, İstanbul: The ISIS Press 2004, s. 170-190.

Aksan, Virginia: "Ottoman Military Recruitment Strategies in the Late Eighteenth Century", Ottomans and Europeans: Contacts and Conflicts, İstanbul: The ISIS Press 2004, s. 191-208.

Aksan, Virginia: "Whatever Happened to the Janissaries? Mobilization for the 1768-1774 Russo-Ottoman War”, Ottomans and Europeans: Contacts and Conflicts, İstanbul: The ISIS Press 2004, s. 209-222.

Aksan, Virginia: Ottoman Wars 1700-1870 an Empire Besieged, London, New York, Boston, San Francisco: Pearson 2007.

Aksan, Virginia: Ottomans and Europeans: Contacts and Conflicts, İstanbul, The ISIS Press 2004 .

Anastasopoulos, Antonis: "Lighting the Flame of Disorder: Ayan Infighting and State Intervention in Ottoman Karaferye, 1758-59”, International Journal of Turkish Studies 8, (2002), s. 73-88.

Anastasopoulos, Antonis (ed.): Provincial Elites in the Ottoman Empire, Halcyon Days in Crete V a Symposium Held in Rethymno 10 - 12 January 2003, Rethymno: Crete University Press 2005.

Anastasopoulos, Antonis, and Elias Kolovos (eds.): Ottoman Rule and the Balkans, 17601850 Conflict, Transformation, Adaptation - Proceedings of an International Conference Held in Rethymno, Greece, 13-14 December 2003, Rethymno: University of Crete Department of History and Archaeology 2007.

Aydın, Muhammed: Sivas'ta Âan Aileleri, 1740-1850 Sivas: Sivas Belediyesi 2015.

Bakan, Nilüfer: Salnamelere Göre Tanzimat'tan Cumhuriyet'e Kütahya Sancağı'nın Sosyo-Ekonomik Profili, Yüksek Lisans Tezi, Osmangazi Üniversitesi, 2007.

Barbir, Karl: “One Marker of Ottomanism: Confiscation of Ottoman Officials' Estates”, Baki Tezcan and Karl K. Barbir (eds.), Identity and Identity Formation in the Ottoman World, a Volume of Essays in Honor of Norman Itzkowitz, Madison, Wisconsin: The Center for Turkish Studies at the University of Wisconsin and The University of Wisconsin Press 2007, s. 135-146.

Barkey, Karen: Empire of Difference the Ottomans in Comparative Perspective, Cambridge, New York: Cambridge University Press 2008.

Baykal, Bekir Sıtkı: “A’yanlık Müessessesinin Düzeni Hakkında Belgeler,” Belgeler - Türk Tarih Belgeleri Dergisi, 1 (1964), s. 221-227. 
Bozkurt, Öznur Kutluğ: Kütahya Şer’iye Sicilleri 8 Numaralı Defterinin Transkripsiyonu ve Değerlendirilmesi, Yayınlanmamış Yüksek Lisans Tezi Dumlupınar Üniversitesi, 2006.

Cahen, Claude: “A Propos Des Shuhud”, Studia Islamica, 31 (1970), s. 71-79.

Canbakal, Hülya: 17. Yüzyılda Ayntâb Osmanlı Kentinde Toplum ve Siyaset. çev. Zeynep Yelçe, İstanbul: İletişim Yayınları 2009.

Cezar, Yavuz: "Bir Âyanın Muhallefatı, Havza ve Köprü Kazaları Âyanı Kör İsmail-Oğlu Hüseyin, Müsadere Olayı ve Terekenin İncelenmesi,” Belleten, 41 (1977), s. 41-78.

Cezar, Yavuz: "Comments on the Financial History of the Ottoman Provinces in the 18th Century: A Macro Analysis", Essays on Ottoman Civilization, Praha: Academy of Sciences of the Czech Republic Oriental Institute - Proceedings of the XIIthe Congress of the CIEPO 1996, Prague: Academy of Sciences of the Czech Repulic, Oriental Institute 1998, s. 85-92.

Cezar, Yavuz: "From Financial Crisis to the Structural Change: The Case of the Ottoman Empire in the Eighteenth Century", Oriente Moderno 18 (1999), s. 49-54.

Çınar, Hüseyin: “18. Yüzyılda Ayıntab’da Bir Yerel Gücün Yükselişi ve Düşüşü: Battalzâdeler”, XIV. Türk Tarih Kongresi, Ankara: Türk Tarih Kurumu 2005, s. 431452.

Çoşar, Nevin, Sevtap Demirci: "Incorporation into the World Economy: From Railways to Highways", Middle Eastern Studies 45 (2009), s. 19-31.

Dadaş, Cevdet, Atilla Batur: Osmanlı Arşivi Belgelerinde Kütahya 1. Cilt, Kütahya: Kütahya Belediyesi, Kütahya Kültür ve Tarihini Araştırma Merkezi Yayınları 1999.

Dağ, Rabia Canpolat: 11 Numaralı Kütahya Şeri’iyye Sicili (1819-1820m /1234-1236), Yüksek Lisans Tezi, Fırat Üniversitesi, 2003.

Dimitropoulos, Dimitris: "Aspects of the Working of the Fiscal Machinery in the Areas Ruled by Ali Paşa”, Antonis Anastasopoulos, Elias Kolovos (eds.), Ottoman Rule and the Balkans, 1760-1850 Conflict, Transformation, Adaptation - Proceedings of an International Conference Held in Rethymno, Greece, 13-14 December 2003, Rethymno: University of Crete Department of History and Archaeology, 2007, s. 61-72.

Doumani, Beshara: Rediscovering Palestine: Merchants and Peasants in Jabal Nablus, 17001900 Berkeley: University of California Press 1995.

Erdoğan, Meryem Kaçan, Meral Bayrak Ferlibaş, Kamil Çolak: Tirsiniklizâde İsmail A ̆ga ve Dönemi (1796-1806) İstanbul: Yeditepe Yayınevi 2009.

Ergene, Boğaç: Local Court, Provincial Society and Justice in the Ottoman Empire: Legal Practice and Dispute Resolution in Çankır and Kastamonu (1652-1744), Leiden: E.J. Brill 2003.

Erol, Hüseyin: 13 Numaralı Kütahya Şer'iyye Sicili Transkribe ve Değerlendirmesi, Yüksek Lisans Tezi Kırıkkale Üniversitesi, 1997. 
Faroqhi, Suraiya: “18. Yüzyıl Bursa’sında Zengin Olmak: Debbağ Hacı İbrahim’in Serveti”, Osmanl Dünyasında Üretmek, Pazarlamak, Yaşamak, İstanbul: Yapı Kredi Kültür Sanat Yayıncilık 2008, s. 199-218.

Faroqhi, Suraiya: "Wealth and Power in the Land of Olives: Economic and Political Activities of Müridzade Hacı Mehmed Ağa, Notable of Edremit”, Çağlar Keyder, Faruk Tabak (eds.), Landholding and Commercial Agriculture in the Middle East, New York: State University of New York Press, 1999, s. 77-96.

Fleming, K. E: The Muslim Bonaparte Diplomacy and Orientalism in Ali Pasha's Greece, Princeton New Jersey: Princeton Modern Greek Studies, Princeton University Press 1999.

Genç, Mehmet. "Osmanlı Maliyesinde Malikane Sistemi”, Osmanlı Imparatorluğunda Devlet ve Ekonomi, İstanbul: Ötüken Neşriyat, 2000, s. 99-152.

Georgieva, Gergana: "Administrative Structure and Government of Rumelia in the Late Eighteenth and Early Nineteenth Centuries: The Functions and Activities of the Vali of Rumelia", Antonis Anastasopoulos ve Elias Kolovos, (eds.), Ottoman Rule and the Balkans, 1760-1850 Conflict, Transformation, Adaptation-Proceedings of an International Conference Held in Rethymno, Greece, 13-14 December 2003, Rethymno: University of Crete Department of History and Archaeology, 2007, s. 3-20.

Günay, Nilüfer Alkan: "Müsaderenin Sosyal ve Ekonomik Bir Analizi: 18. Yüzyıl Sonlarında Bursa'da Yapılan Müsadereler”, Belleten 76 (2012), s. 793-817.

Güngör, Ekrem: 1 Numaralı Kütahya Şer’iyye Sicili (2. Bölüm) Transkripsiyonu ve Kritiği, Yüksek Lisans Tezi, Dumlupınar Üniversitesi, 2006.

Hathaway, Jane: The Arab Lands under Ottoman Rule 1516-1800, London New York San Francisco: Pearson Longman, Harlow 2008.

Hathaway, Jane: "The Household: An Alternative Framework for the Military Society of Eighteenth-Century Ottoman Egypt", Oriente Moderno 18 (1999), s. 57-66.

Hathaway, Jane: The Politics of Households in Ottoman Egypt: The Rise of the Qazdaglis Cambridge, New York: Cambridge University Press 1997.

Hourani, Albert: "Ottoman Reform and the Politics of Notables", Beginnings of Modernization in the Middle East, William R Polk, Richard Chambers (eds.), Chicago: The University of Chicago Press 1968, s. 41-68.

İnalc1k, Halil: "Centralization and Decentralization in Ottoman Administration", Studies in 18th Century Islamic History, Thomas Naff ve Roger Owen (eds.), Carbondale and Edwards-Ville: Southern Illinois University 1977, s. 27-52.

İnalcık, Halil: "Sened-i Ittifak ve Gülhane Hatt-1 Hümâyûnu”, Osmanlı İmparatorluğu, Toplum ve Ekonomi, İstanbul: Eren Yayıncilık 1993, s. 343-359.

İnalcık, Halil, Mehmet Seyitdanlığlu (eds.), Tanzimat, Değişim Sürecinde Osmanlı Imparatorlŭ̆u, İstanbul: Türkiye İş Bankası Kültür Yayınları, 2012. 
Karacagil, Ö. Kürşad: 6 Numaralı Kütahya Şer’iye Sicili Transkripsiyonu ve Edisyon Kritiği, Yüksek Lisans Tezi, Dumlupınar Üniversitesi, 2002.

Keyder, Çağlar, Faruk Tabak, (Eds), Landholding and Commercial Agriculture in the Middle East, New York: State University of New York Press, 1991.

Khoury, Dina Rizk: Osmanl Imparatorluğu'nda Devlet ve Taşra Toplumu, Musul 15401834, çev. Ülkü Tansel, İstanbul: Tarih Vakfı Yurt Yayınları, 1999.

Khoury, Dina Rizk: “The Ottoman Centre Versus Provincial Power-Holders: An Analysis of the Historiography", The Cambridge History of Turkey, the Later Ottoman Empire, 1603-1839, Suraiya N. Faroqhi (ed.), Cambridge: Cambridge University Press, 2009, s. 135-157.

Koç, Mustafa: Germiyanoğulları Beyliği’nde İlmî ve Kültürel Hayat, Yüksek Lisans Tezi, Dokuz Eylül Üniversitesi, 2007.

Lowry, Heath W. The Nature of the Early Ottoman State, Albany: State University of New York Press, 2003.

Masters, Bruce: "Semi-Autonomous Forces in the Arab Provinces", The Cambridge History of Turkey, the Later Ottoman Empire, 1603-1839, Suraiya N. Faroqhi (ed.), Cambridge: Cambridge University Press, 2009, s. 186-206.

McGowan, Bruce: "The Age of the Ayans 1699-1812", An Economic and Social History of the Ottoman Empire 1600-1914, Donald Quataert, Halil İnalcık (eds.), Cambridge: Cambridge University Press 1997, s. 637-758.

Meriwether, Margaret L.: The Kin Who Count, Family and Society in Ottoman Aleppo, 1770-1840 Austin: University of Texas Press 1999.

Nagata, Yuzo: "Karaosmanoğlu Hacı Hüseyin Ağàya Ait Bir Tereke Defteri”, IX. Türk Tarih Kongresi, Ankara: Türk Tarih Kurumu, 1988, s. 1055-1063.

Nagata, Yuzo: Muhsin-Zâde Mehmed Paşa ve Ayanlık Müessesesi, Tokyo: Institute for the Study of Languages and Cultures of Asia and Africa, 1976.

Nagata, Yuzo: Tarihte Ayanlar Karaosmanoğulları Üzerine Bir İnceleme, Ankara: Türk Tarih Kurumu 1997.

Nagata, Yuzo, Feridun Emecen, “Bir Ayanın Doğuşu: Karaosmanoğlu Hacı Mustafa'ya Ait Belgeler”, Belgeler - Türk Tarih Belgeleri Dergisi 25 (2004), s. 1-73.

Öksüz, Melek: Onsekizinci Yüzyılın İkinci Yarısında Trabzon, Trabzon: Serander, 2006.

Özkaya, Yücel: Osmanlı Imparatorluğu’nda Ayanlık, Ankara: Türk Tarih Kurumu Bas1mevi, 1994.

Polat, Süleyman: 17. Yüzyılda Mühimme Defterlerine Göre Kütahya, Yüksek Lisans Tezi, Dumlupınar Üniversitesi, 2005.

Quataert, Donald: The Ottoman Empire 1700-1922, New Approaches to European History, Cambridge: Cambridge University Press 2000. 
Sadat, Deena: "Rumeli Ayanları: The Eighteenth Century", Journal of Modern History 44 (1972), s. 346-363.

Salzmann, Ariel. "An Ancien Regime Revisited: Privatization and Political Economy in the 18th Century Ottoman Empire." Politics and Society 21/4 (1993), 393 - 424.

Şahin, Canay: "The Economic Power of Anatolian Ayans of the Late Eighteenth Century: The Case of Caniklizâdes", International Journal of Turkish Studies 11 (2005), s. $29-49$.

Süreyya, Mehmed, Sicill-i Osmanî, Nuri Akbayar, (ed.), İstanbul: Tarih Vakfı Yurt Yayınlar1 1996.

Üstün, Kadir: The New Order and Its Enemies: Opposition to Military Reform in the Ottoman Empire, 1789-1807, Doktora Tezi, Columbia University, 2013.

Uysal, A. Osman: Germiyanoğullar Beyliğinin Mimarî Eserleri, Ankara: Atatürk Kültür Merkezi Başkanlığı Yayınları 2006.

Uzunçarşılı, İsmail Hakkı: Bizans ve Selçukiylerle Germiyan ve Osman Oğulları Zamanında Kütahya Şehri, İstanbul: Devlet Matbaası 1932.

Varlık, Mustafa Çetin: Germiyan-Oğulları Tarihi (1300-1429), Ankara: Ankara Üniversitesi Yayınları 1974.

Varlık, Mustafa Çetin: "Germiyanoğulları Beyliği”, Anadolu Selçukluları ve Beylikler Dönemi, Sosyal ve Siyasal Hayat, Ahmet Yaşar Ocak (ed.), Ankara: T.C Kültür ve Turizm Bakanlığ 2006 , s. 153-159.

Varlık, Mustafa Çetin: “Kütahya’nın Şehzade Sancağı Olarak İdaresi”, Marmara Üniversitesi Türklük Araştırmaları Dergisi, 5 (1989), s. 314-324.

Yavuz, Mustafa: Kütahya Şer'iye Sicilleri 15 Numaralı Defterinin Transkripsiyonu ve Değerlendirilmesi, Yüksek Lisans Tezi, Dumlupınar Üniversitesi, 2009.

Yaycıoğlu, Ali, The Provincial Challenge: Regionalism, Crisis and Integration in the Late Ottoman Empire (1792-1812), Doktora Tezi, Harvard University, 2008.

Yaycıoglu, Ali: "Provincial Power-Holders and the Empire in the Late Ottoman World: Conflict or Partnership?", C. Woodhead (ed.), The Ottoman World, London: Routledge Press 2011, s. 436-465.

Yaycioğlu, Ali: Partners of the Empire, The Crisis of the Ottoman Order in the Age of Revolutions, Stanford, California: Stanford University Press, 2016.

Yıldız, Aysel: Vaka-yı Selimiyye or the Selimiyye Incident, a Study of the May 1807 Rebellion, Doktora Tezi, Sabancı Universitesi, 2008.

Zens, Robert W: "In the Name of the Sultan: Hacı Mustafa Pasha of Belgrade and Ottoman Provincial Rule in the Late 18th Century", International Journal of Middle East Studies 44 (2012), s. 129-146.

Zens, Robert W: "Provincial Powers: The Rise of Ottoman Local Notables," History Journal 3 (2011), s. 433-447. 